Article

\title{
Idealisations of Dynamic Modelling for Railway Ballast in Flood Conditions
}

\author{
Sakdirat Kaewunruen ${ }^{1, *(1)}$ and Tao Tang ${ }^{2}$ \\ 1 Department of Civil Engineering, School of Engineering, The University of Birmingham, \\ Edgbaston B15 2TT, UK \\ 2 China Communication Construction Company (CCCC)'s First Harbor Engineering Company, Building No.8, \\ Shipping Services Center, Yuejin Road, Tianjin Port Bonded Zone, Tianjin 300461, China; \\ tangtao4650@icloud.com \\ * Correspondence: s.kaewunruen@bham.ac.uk
}

Received: 3 April 2019; Accepted: 25 April 2019; Published: 29 April 2019

\begin{abstract}
As the main component of a ballasted railway system, railway ballast is frequently used by the railway industry to enhance constructability and practicality. Numerous studies into train-track interactions focused on ballast modelling and idealisation in completely dry environments, but recent studies have found that, in extreme weather such as floods, water can clog natural ballast beds and change the initial state of their properties. Ballast models used in multi-body simulations have been mostly developed based on the instrumented impact hammering method considering the ballast as a spring/dashpot. The single degree of freedom (SDOF) idealization for ballast enables a non-destructive field testing technique for monitoring of railway components in practice. In this study, the suitability of the idealization of ballast for dynamic characteristics has been evaluated. A series of experiments have been performed with a variety of ballast conditions in flooding levels from 0 to $40 \mathrm{~cm}$, with a frequency range of $0-500 \mathrm{~Hz}$. The results clearly show that the increase in the flood level will result in increasing dynamic damping of more than $50 \%$ of dry natural ballast whilst reducing its stiffness and natural frequency. The novel insights are of great significance for exploring the non-linear dynamic traits of ballast in extreme environments, which can be integrated into the coupled train-track analysis that can better express more realistically the dynamic train-track interaction and load transfer mechanism of flooded railway tracks.
\end{abstract}

Keywords: flooded ballast; dynamic behaviors; SDOF system; idealisation model analysis

\section{Introduction}

Modern railway tracks have evolved over centuries with operational speeds and economic viability. Today, there are two types of modern railway tracks: ballasted and ballastless tracks. The use of railway ballast for rapid construction of low- to medium-speed tracks $(<250 \mathrm{~km} / \mathrm{h})$ has been adopted over several decades [1]. Railway ballast or granular media is a main track component used in ballasted railway tracks worldwide [2]. It is mostly manufactured from crushed rock-based local materials from various sources such as crushed igneous rocks (granite, rhyolite, decite, basalt, quartzite or latite), crushed metamorphic rocks, crushed sedimentary rocks, crushed gravel (from rivers, lakes), or sometimes even from waste products (such as crushed slag, chitter) [3-8]. Early railways did not place ballast as being highly significant to the makeup of a successful design of the permanent way. This position gradually changed and the performance of the ballast material is now considered important in the design process. Ballast is required to fulfil the task of maintaining the track in good alignment both horizontally and vertically. Track geometry deterioration can be rectified and restored quickly and cost-effectively over ballast [9-15]. To gain these benefits, railway ballast must have the following characteristics: 
- Durable to be able to absorb the loads imposed by the sleepers and transmit the loads to the sub-grade without undue breakdown;

- Hard-wearing with high abrasion resistance in both wet and dry conditions;

- Angular with sufficient bulk density to resist movement of the track both longitudinally and laterally; and

- Particle size to allow packing and transfer of the loads of the track but with sufficient void space to allow free draining to assist shedding of all moisture.

Both the ballast and capping layer material can be seen in Figure 1. The functions or roles expected of the ballast layer have changed with time and the evolutionary development of railway technology. There is some discussion of the functions of ballast in the references, "Railroad Engineering" (Ch. 21) by W.W. Hay, "British Rail Track" (Ch. 2), by the Permanent Way Institution, "A Review of Track Design Procedures" (Vol. 2, Ch. 4) by Jeffs and Tew, and "Track Geotechnology and Substructure Management", by Selig and Waters [2,15].
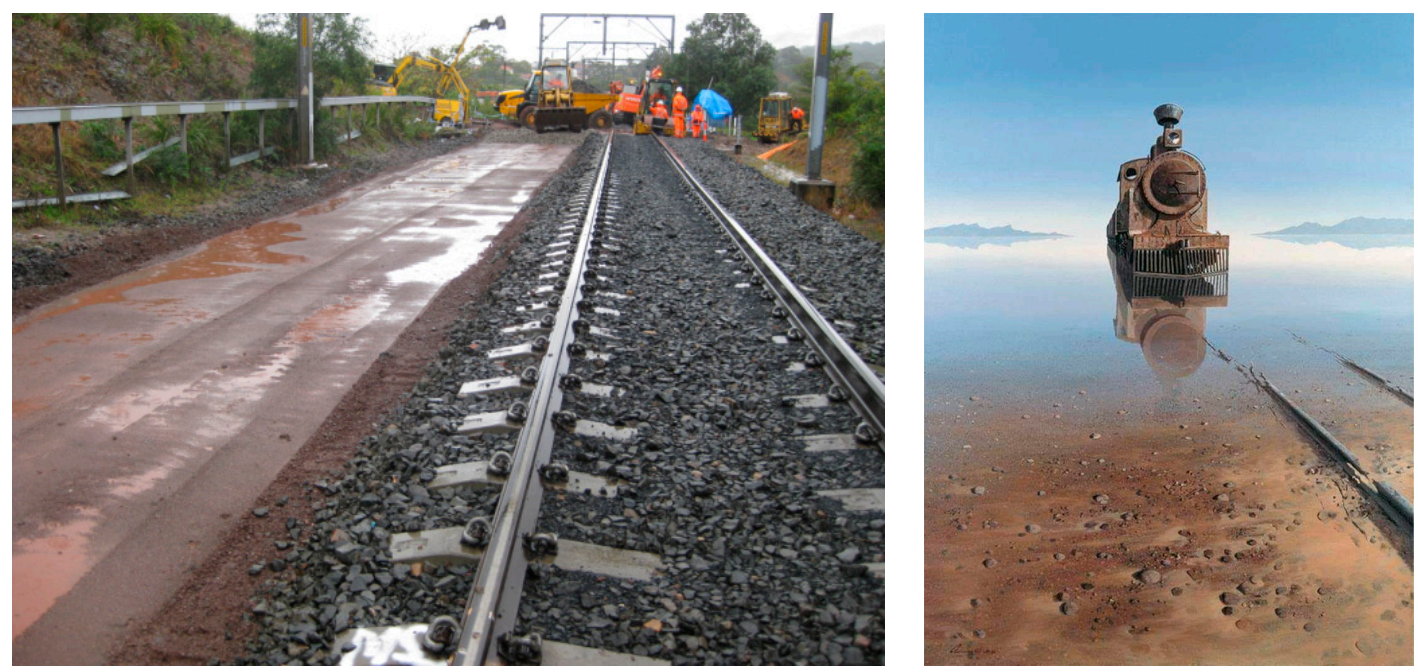

Figure 1. A typical ballasted track (left). The capping layer called 'sub-ballast' is prepared by compacting roller prior to laying ballast. In reality, the capping layer and subgrade are non-homogenous and cannot be accurately modelled by a simple constant elastic half-space nor a continuous layer. These layers are thus designed under higher safety margin or higher factor of safety by the allowable stress design concept $[16,17]$. The design takes into account the accumulated strains of these layers, which are often limited over a target design period (e.g., 15-25 years). Track maintenance cost function of deteriorated ballasted tracks will increase over time. The right figure shows a train standing in a flooded track.

The functions of ballast can be divided into two criteria:

- Primary Functions: the original purpose of ballast; and

- Secondary Functions: the characteristics of the material that enable the ballast to fulfil and continue to fulfil its primary function and those functions that have been added with technology improvements and community expectations.

The primary functions of the ballast are to provide a uniform elastic vertical support; to fix the track in position laterally and longitudinally; and to facilitate the correction of the track level and line enhancing constructability and maintainability of a railway network [1-4]. The secondary functions of ballast are to allow surface water to drain rapidly; to inhibit the growth of vegetation; to compensate for the presence of fouling material, to reduce noise; to provide electrical insulation of one rail from the other; and, to moderate the effect of frost heave in cold climates and movement due to climate uncertainties [3,18-26]. 
Railway ballast is installed under railway sleepers to transfer the static and quasi-static stress (already filtered by rail pads and sleepers) from axle loads and wheel loads from both regular and irregular train movements, as shown in Figure 2. In accordance with the design and analysis, numerical models of a railway track have been employed to aid the track engineers in failure and maintenance predictions [27-31]. Current numerical models or simulations of railway tracks mostly consider the track components in a perfect situation or in a normal weather condition. The effect of flooding on the dynamic behaviour of railway ballast has never been investigated, although it is evident that climate uncertainty has a significant influence on railway networks that affects the serviceability and performance of railway tracks [32,33]. It should be noted that for safety reasons, trains do not usually run on flooded railway tracks. The primary reason is due to a lack of information, either about the dynamic characteristics of railway ballast under variable flooding conditions, or about the dynamic train-track modelling to capture the flooding conditions. This paper is the first to present dynamic modal identification of railway ballast in flooding conditions. It also highlights the experimental results obtained as part of the railway engineering research activities at the University of Birmingham (UoB) aimed at improving the dynamic performance and modelling of railway tracks globally. The proposed relationships could be incorporated into track analysis and design tools for a more realistic representation of the dynamic train-track interaction and load transfer mechanisms under extreme events.
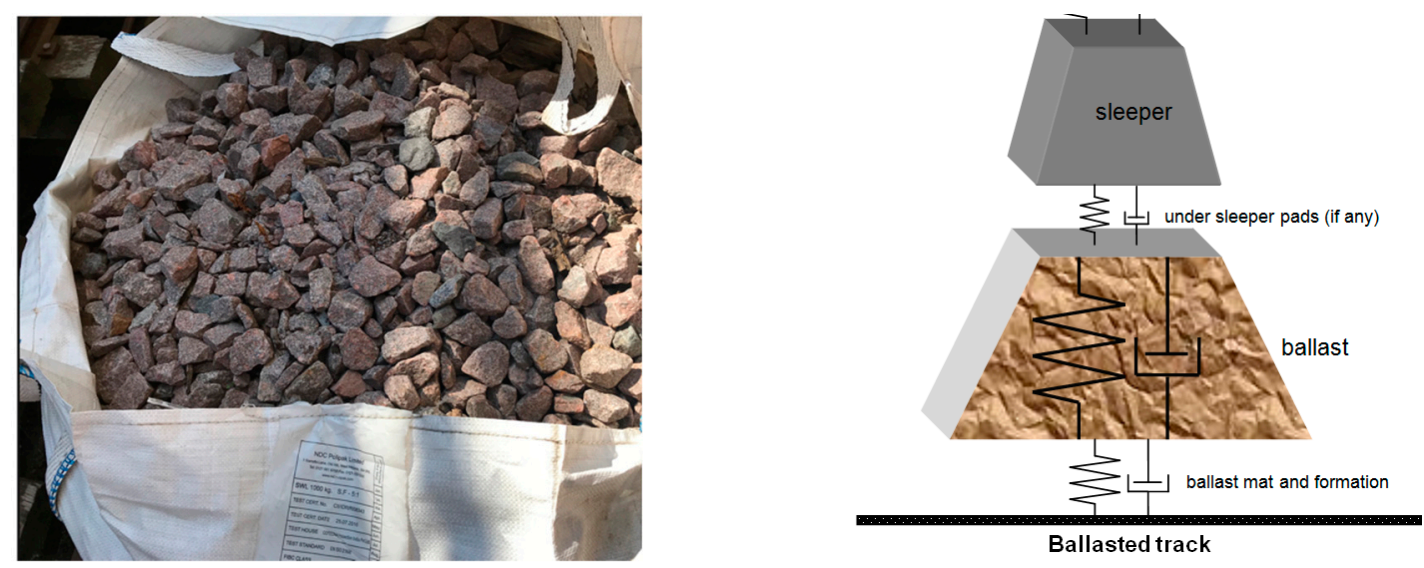

Figure 2. Natural ballast (left) and ballast idealization as spring-dashpot (right).

\section{Materials and Methods}

\subsection{Materials}

Natural ballast (Figure 2) used in the UK railway tracks was kindly supplied by Network Rail.

\subsubsection{Types of Mass}

To identify the scale effect of track components, there are three types of mass being tested, shown in Table 1.

- Concrete block (Figure 3a), which has been manufactured in Civil lab at the University of Birmingham.

- Half-concrete sleeper (Figure 3b), which has been supplied by Network Rail.

- Half-FFU (fibre reinforced foamed urethane) sleeper (Figure 3c) is used, which is a new innovative composite material (wood-like) that combines the durability of plastic with the machinability of wood [34]. The FFU material has been supplied by Sekisui. 
Table 1. Different types of mass.

\begin{tabular}{cccc}
\hline Mass Types & Concrete Block & Concrete Sleeper & FFU Sleeper \\
\hline Size $\left(\mathrm{mm}^{3}\right)$ & $150 \times 150 \times 150$ & $900 \times 250 \times 160$ (average) & $820 \times 260 \times 160$ \\
Contact area $\left(\mathrm{mm}^{2}\right)$ & 22,500 & 225,000 & 213,200 \\
Mass $(\mathrm{kg})$ & 7.815 & 110.3 & 23.0 \\
\hline
\end{tabular}

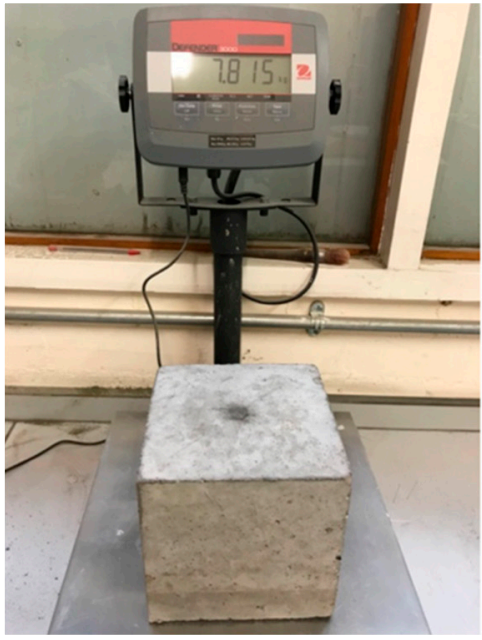

(a)

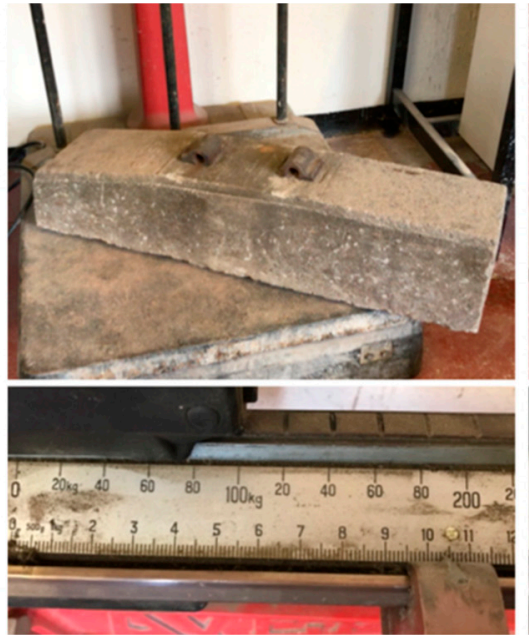

(b)

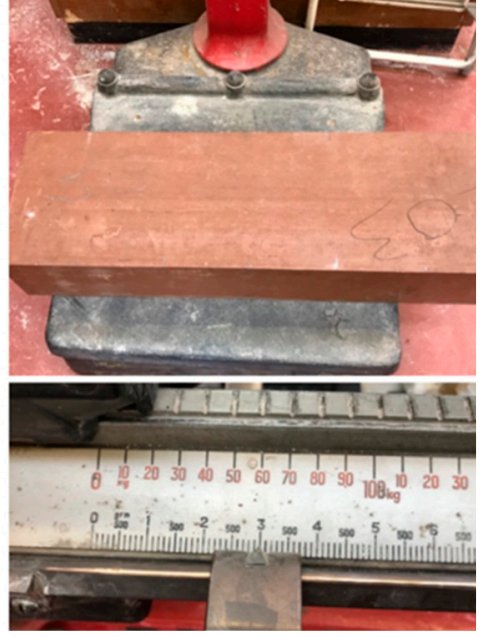

(c)

Figure 3. (a) Concrete block (b) concrete sleeper (c) FFU sleeper.

\subsubsection{The Preparation of the Ballast Bed}

\section{- Large-Scale Ballast Bed}

This is a self-made $1.85 \times 0.9 \times 0.5 \mathrm{~m}$ wooden box structure (Figure $4 \mathrm{a}$ ), in which three transparent plastic plates of plywood are connected by drill bolts, and then silicone is applied at each joint for sealing. The side mark is used to control the flooding level every $50 \mathrm{~mm}$. The inlet/outlet pipes can be used to adjust the water level repeatedly. At the same time, a thermometer is placed inside the box to record the water temperature in time. The bed can accommodate a full-scale half sleeper to enable similarity of field tests.

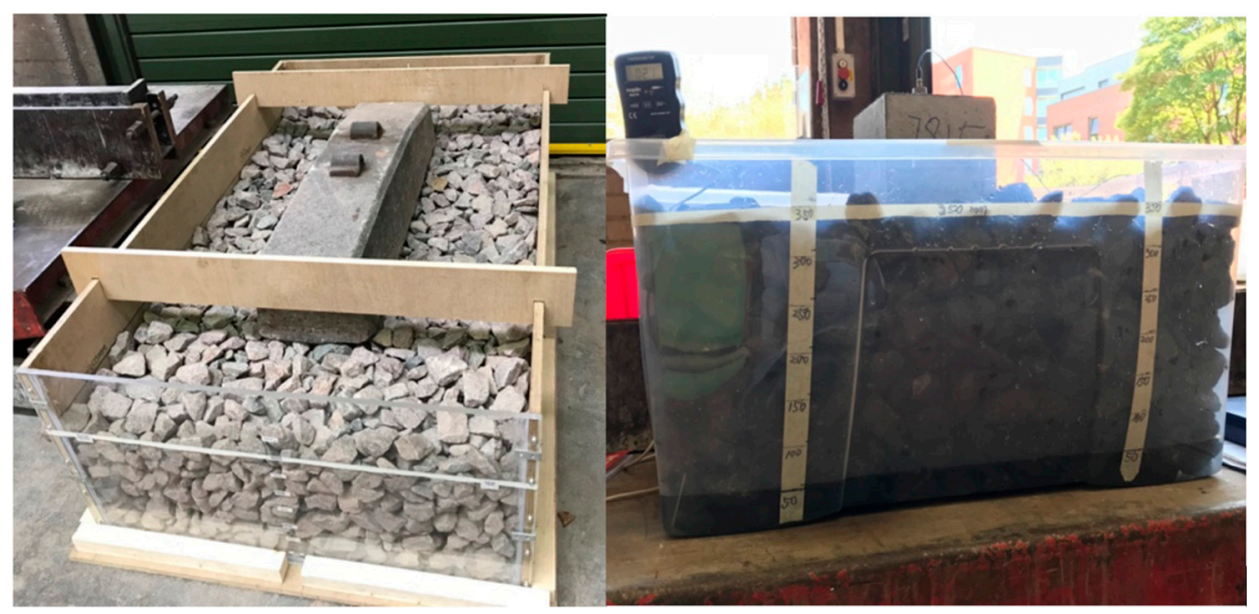

(a)

(b)

Figure 4. (a) Large-scale ballast bed. (b) Small-scale ballast bed. 
- Small-Scale Ballast Bed

The small container is a transparent plastic box (Figure $4 \mathrm{~b}$ ) with a size of $0.795 \times 0.395 \times 0.40 \mathrm{~m}$, which is mainly used for preliminary experiments and compared with the large-scale ballast bed.

\subsection{Methods}

In this study, a Prosig system (DATs) [34] with the impact hammer and acquisition device is utilized. Datafit curve fitting software has been used for modal parameter identification (using the least square best fitting method). The flood level and water temperature is regularly measured and recoded (as shown in Figure 5).

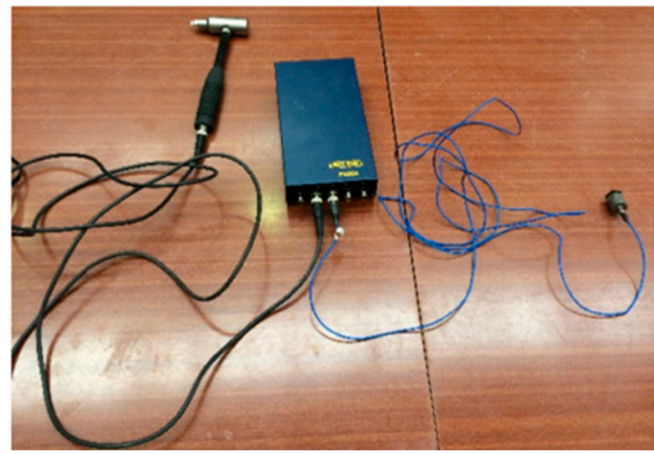

(a)

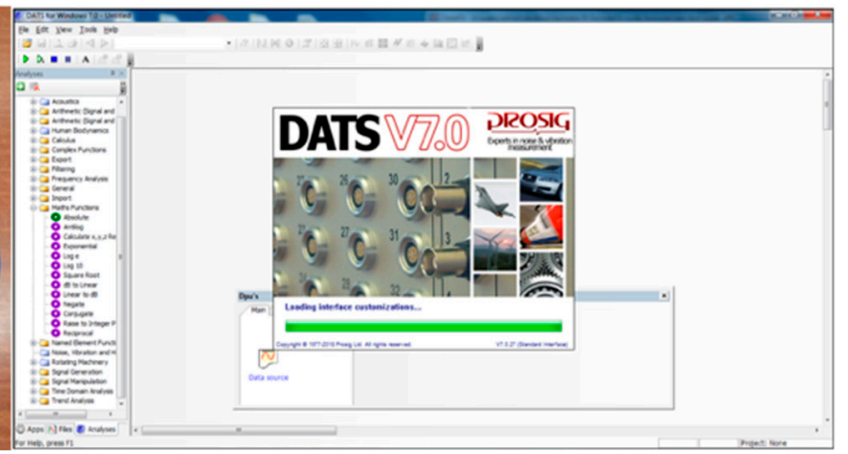

(b)

Figure 5. (a) The impact hammer; (b) acquisition device with DATs software.

This study aims to use a non-destructive test method [35] based on instrumented hammer impact excitation and a signal-processing analysis to measure the vibration response of the structure to impact excitation and then to use Fourier transformation to convert the vibration signals to the frequency response function (FRF) (as shown in Figure 6). The FRF is then used to extract the modal parameters, natural frequency, and its dynamic properties [36].

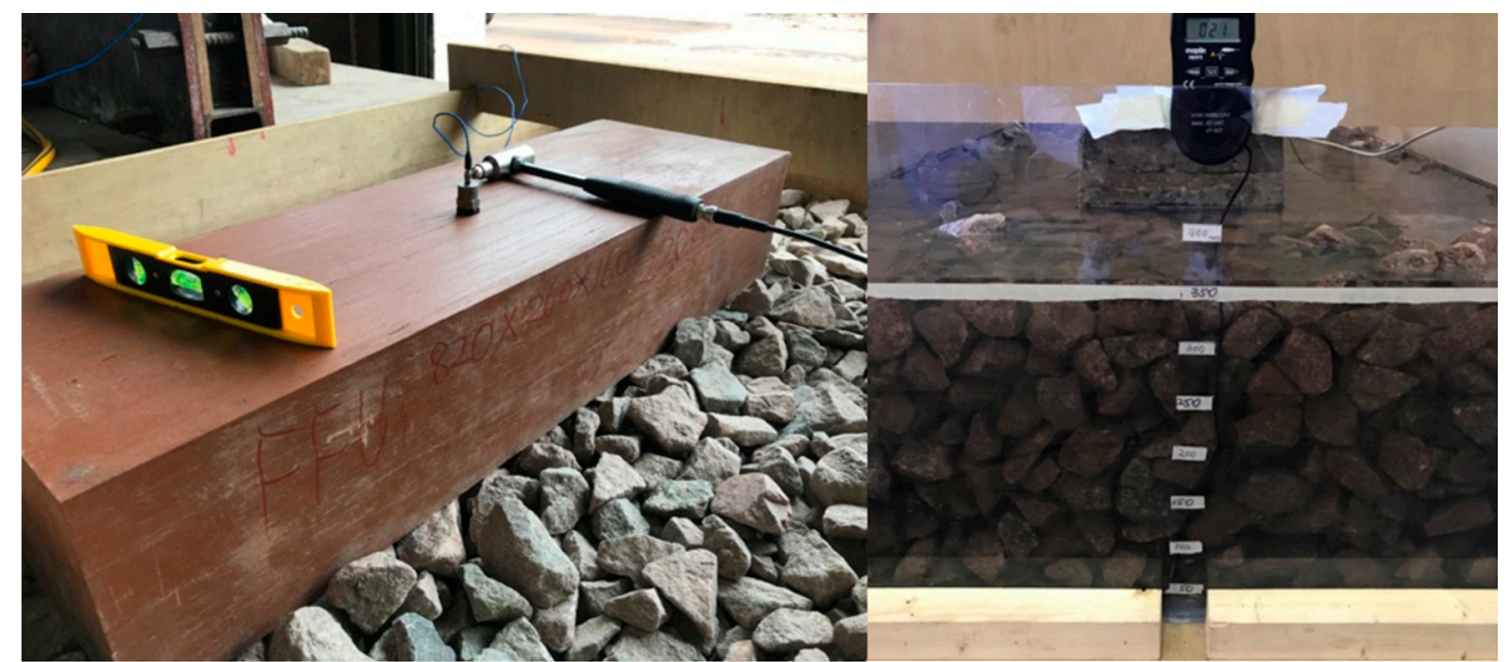

(a) (b)

Figure 6. (a) Level for adjusting the surface of testing mass; (b) thermometers for recording the testing temperature at different water levels.

\subsubsection{Identification of Dynamic Parameters Using an Instrumented Hammer}

If the dynamic properties in the mid- or high-frequency range of materials are determined, the instrumented hammer impact loading and accelerometer recording are suitable tools for modal analysis. 
Its moveable features can effectively avoid blocking the traffic [37]. A series of time recordings can be converted into an average FRF, which is directly related to the material property. The acquisition equipment can be linked to a portable laptop, which captures the data for analyses in a short time (Figure 7). A lumped mass model (single degree of freedom, SDOF) can be idealised for ballast testing, which enable suitable analytical models for best curve fitting in the direct vicinity of the resonant peak.

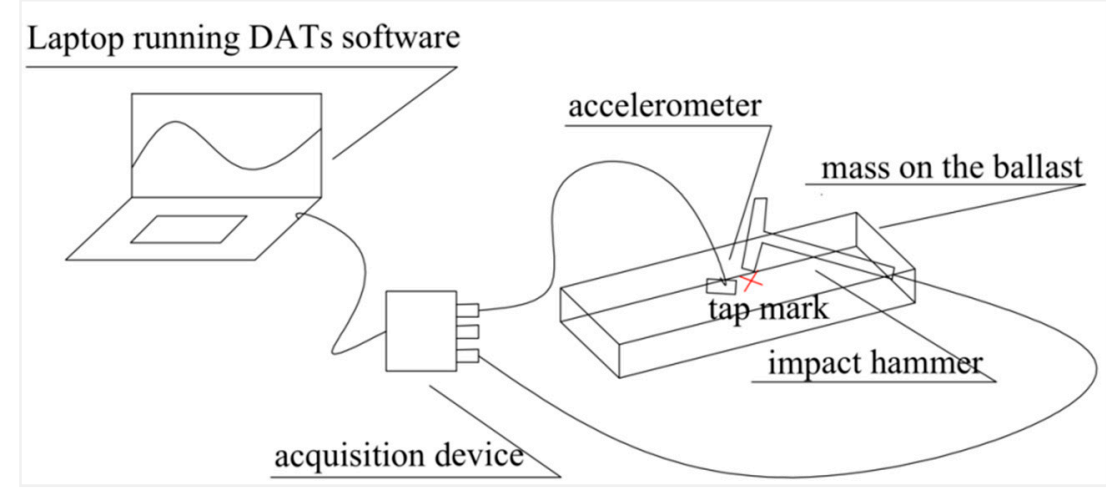

Figure 7. Capture data using the instrumented hammer.

In the SDOF system, the accelerometer can be used to measure the response at the remaining points and then a series of FRFs can be obtained; then, the natural frequencies and corresponding mode shapes can be extracted using modal analysis software (DATs).

\subsubsection{Simulating Floods in Ballast}

The flood condition can be simulated by using different water levels representing various flood conditions and measuring the dynamic behaviors of every level (increase every $10 \mathrm{~cm}$ from 0 to $40 \mathrm{~cm}$ ), as illustrated in Figure 8. In this study, the emphasis is placed on the change in ballast properties. Influences of soils undermined by floods are outside the scope of this study.

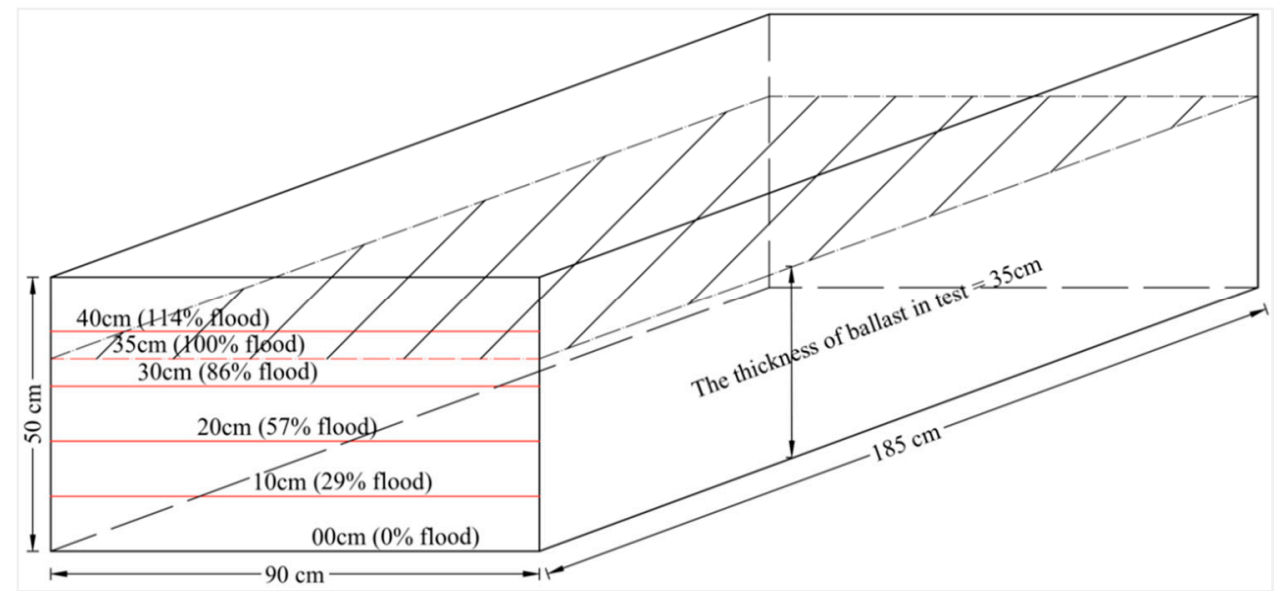

Figure 8. The flooding ballast at different levels.

\subsubsection{Model Built Using Fourier Transformation}

Dynamic characteristics of ballast represented by an elastic spring and dashpot component in the vertical direction can be obtained from the motion and frequency relationship of the object using the Fourier transformation formula. Fourier transformation is the frequency domain representation of the vibration signal. The simplest form of dynamic characteristics in the vertical direction, which 
is commonly used in coupled train-track interaction models, can be described by the well-known equation of motion [38].

$$
M \ddot{X}+C \dot{X}+K X=F(t)
$$

The displacement function $X(t)$ can be written as:

$$
\begin{gathered}
X=A e^{-i \omega t} \\
\dot{X}=-i \omega A e^{-i \omega t} \\
\ddot{X}=-\omega^{2} A e^{-i \omega t} \\
A e^{-i \omega t}\left(-\omega^{2} M-i C \omega+K\right)=F(t)
\end{gathered}
$$

According to the well-known Euler formula in complex analysis (illustrated in Figure 9), we can obtain:

$$
e^{i \varphi}=\cos \varphi+i \sin \varphi
$$

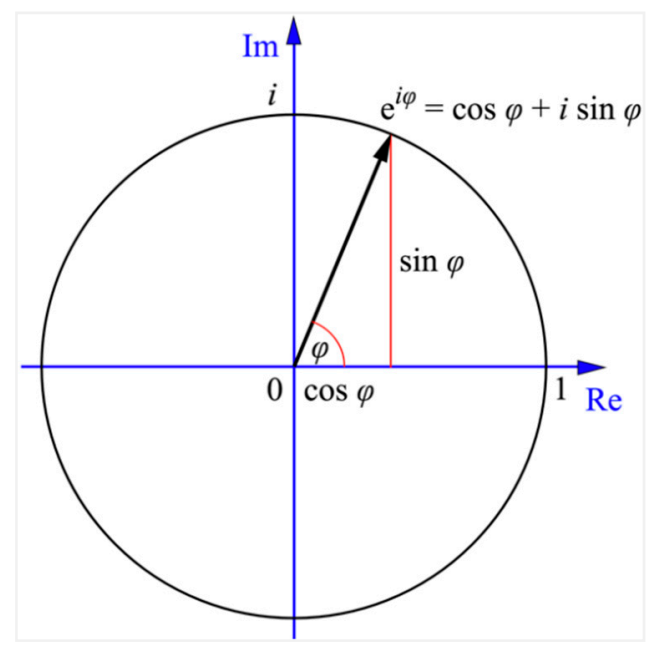

Figure 9. Euler's formula.

Note that:

$$
\begin{gathered}
A(\cos \varphi-i \sin \varphi)\left(-\omega^{2} M-i C \omega+K\right)=F(t) \\
\frac{A}{F}=\frac{1}{\left.\left(K-\omega^{2} M\right) \cos \varphi-C \omega \sin \varphi-i\left(K-\omega^{2} M\right) \sin \varphi-i C \omega \cos \varphi\right)}
\end{gathered}
$$

Then,

$$
\begin{gathered}
\tan \varphi=-\frac{C \omega}{K-\omega^{2} M}=\frac{-2 \zeta \omega / \omega_{n}}{1-\omega^{2} / \omega_{n}^{2}} \\
\omega_{n}=\sqrt{\frac{k}{m}} \\
\zeta=\frac{c}{2 \sqrt{k m}} \\
\omega=2 \pi f
\end{gathered}
$$

where $M, C$, and $K$ generally represent the effective mass, damping, and stiffness of railway ballast respectively $\omega_{n}, \omega$ represent the natural frequency and radial vibration frequency, and $\zeta$ is the damping ratio. 
Therefore, the magnitude of FRF is given by:

$$
H(\omega)=\frac{A}{F}=\frac{1}{M} \times \frac{1}{\sqrt{\left(2 \zeta \omega / \omega_{n}\right)^{2}+\left(1-\omega^{2} / \omega_{n}^{2}\right)^{2}}}
$$

On this basis, Kelvin and Poynting-Thomson further propose an independent model, which adds a frequency-dependent spring to the original basic model equivalent to the action system of two springs [39].

The dynamic expression of the dynamic characteristics in the vertical direction as shown in Figure 10 can be reformulated as:

$$
\begin{gathered}
M \ddot{X}+\frac{1}{\frac{1}{C \omega}+\frac{1}{K_{1}}} X+K_{2} X=F(t) \\
H(\omega)=\frac{A}{F}=\frac{1}{M} \times \frac{1}{\sqrt{\left(\frac{1}{\frac{M}{C \omega}+\frac{M}{K_{1}}}\right)^{2}+\left(\frac{K_{2}}{M}-\omega^{2}\right)^{2}}}
\end{gathered}
$$

where,

$K_{1}=$ frequency-dependent stiffness $(\mathrm{N} / \mathrm{m})$

$K_{2}=$ frequency-independent stiffness $(\mathrm{N} / \mathrm{m})$

$C_{1}=$ frequency-dependent viscous damping $(\mathrm{Ns} / \mathrm{m})$

$\alpha=$ stiffness fractional coefficient

$$
\alpha=\frac{\omega^{2}}{z^{2}+\omega^{2}}
$$

$\beta=$ damping fractional coefficient

$$
\beta=\frac{z^{2}}{\omega^{2}}
$$

where $\omega$ is the radial frequency $(s-1), \omega=2 \pi f$; and $z$ is the partial inverse loss value $(s-1)$, $z=K_{1} / C_{1}[39]$.

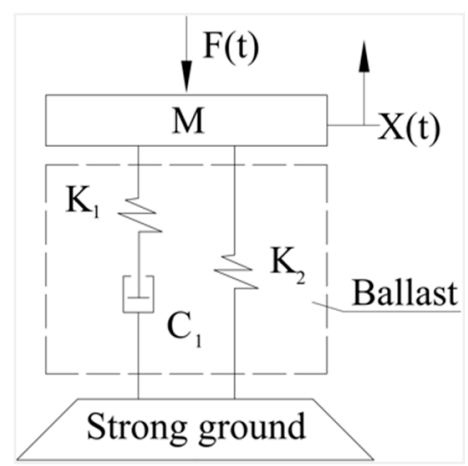

Figure 10. The state dependent model.

According to these coefficients, the integration formula is shown in Table 2.

Table 2. The Kelvin and Poynting-Thomson mechanical model definition.

\begin{tabular}{ccc}
\hline Property & Kelvin Model & Poyning-Thomson Model \\
\hline $\mathrm{K}_{\mathrm{t}}$ & $\mathrm{K}$ & $=\alpha \mathrm{K}_{1}+\mathrm{K}_{2}$ \\
$\mathrm{C}_{\mathrm{t}}$ & $\mathrm{C}$ & $=\alpha \beta \mathrm{C}_{1}$ \\
\hline
\end{tabular}




\subsubsection{Modal Identification by Best Curve Fitting Method}

Modal testing is a non-destructive testing strategy based on the response of structure to vibration excitation. The FRF is the most common data used for assessing modal parameters. It contains vibration spectra computed from the auto-spectrum and cross-spectrum that are measured from the structure [40]. The modal analysis based on the Fast Fourier Transformation [41] of the best curve-fitting approach is widely used to analyse dynamic properties of railway components. The specific approach involves using the least-squares curve to fit the experimental data of FRF, and many curve-fitting tools are available for the modal identification, such as Matlab and Datafit $[35,36]$.

\section{Results}

\subsection{Experimental Results and Justification}

The experimental results obtained from the modal testing of half concrete sleeper over ballast bed are shown in Figures 11 and 12.

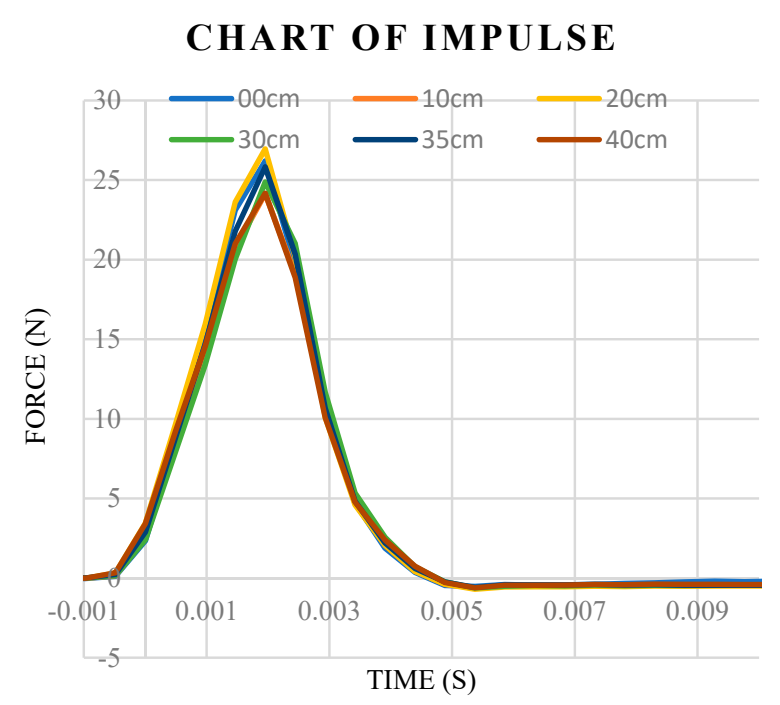

(a)

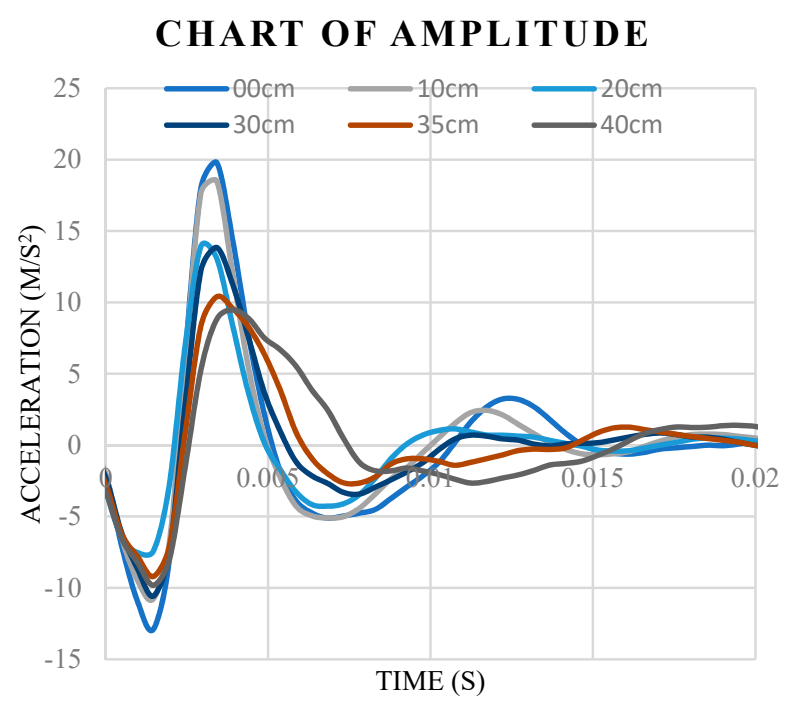

(b)

Figure 11. (a) Change of impulse; (b) change of acceleration. 


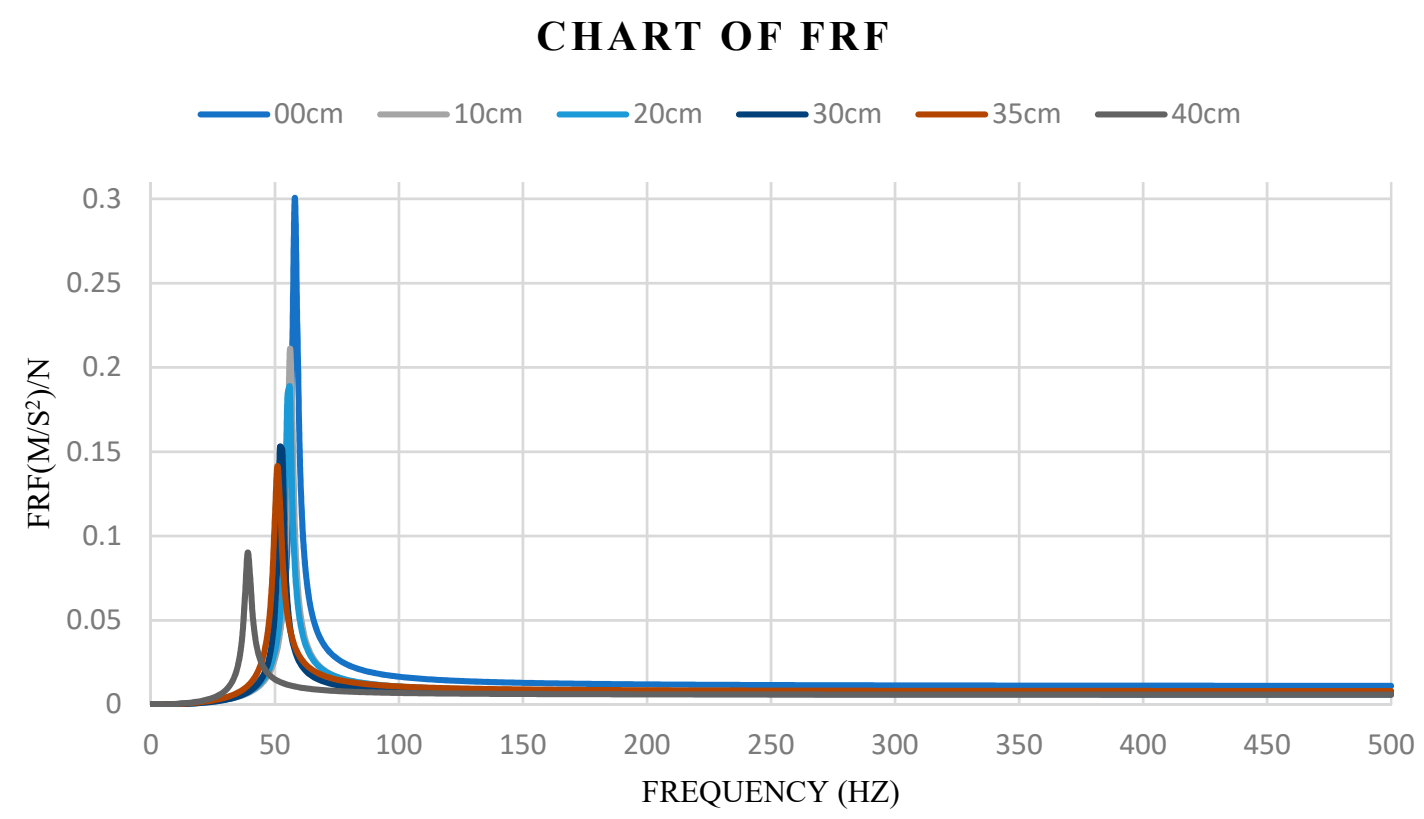

Figure 12. The frequency response function (FRF) change.

\subsubsection{The Transient Forces}

It can be seen from Figure 11a that the impulses are dampened within $0.005 \mathrm{~s}$ and the peak of force occurs approximately at the same time.

\subsubsection{The Changed Acceleration}

Figure $11 \mathrm{~b}$ illustrates the relationship between time and acceleration. From this relationship, it can be seen that the acceleration decreases with the increase of the water level, indicating that the flood effectively increases the system damping, the vibration is weakened, and the secondary amplitude becomes smaller. The flooding environment increases the overall energy consumption of the ballast system.

\subsubsection{The Changed Frequency Response Function (FRF)}

Figure 12 demonstrates that the FRFs tend to decrease with the increase in the water level. After the complete flooding is reached, there is a significant change in the natural frequency of the ballast. According to Equation (10), the mass is considered constant (especially before the completely submerged). The reduction in frequency will result in a reduction in the overall dynamic stiffness of the system.

\subsubsection{Discussion}

The vertical force of the system is instantaneous and basically occurs at the same time. With increasing water level, both the acceleration and FRF decrease by more than $50 \%$, indicating that the speed and size of vibration are significantly slower than initial state (i.e., dry condition), and water enters the ballast and fills the gap, which changes the natural frequency of ballast, resonance frequency gently shifts initially but an obvious change can be observed after the complete flooding.

\subsection{Modal Idealisation Concepts}

In order to obtain an insight into the dynamic properties and the suitability of dynamic model idealisations, it is necessary to identify a variety of appropriate models for ballast representation using the FRF data (or its equivalent impulse response data) in conjunction with the best fitting approach. 
There are 6 possible modelling schemes (as shown in Figure 13) for ballast idealisations. It should be noted that the latter three models are more complex and require a longer computing time for parameters identification, which is not practical for coupled train-track multi-body simulations. This research will thus mainly focus on the first three practical models in details (Models 1-3), which could be realistically adopted in the multi-body simulations.

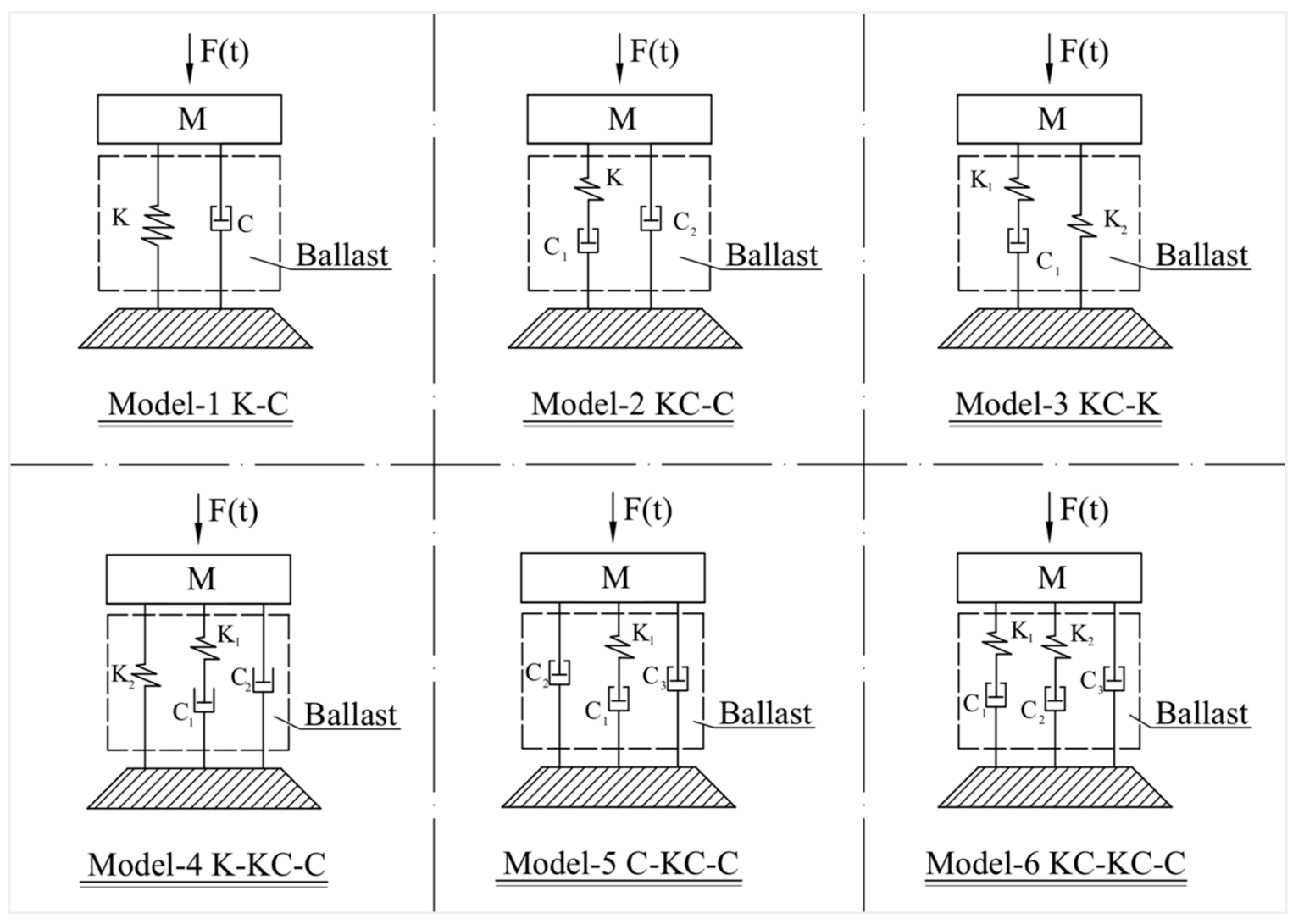

Figure 13. The possible idealisation models.

\subsubsection{Model-1 'K-C'}

\subsubsection{Model Building}

This model is the most commonly used and the most fundamental model, adopted in all of train-track interaction multi-body simulations. It is considered as the benchmark and helps us to understand the basis and trend of the ballast experiments, to analyse the essential relationship of key parameters, and to provide a reference for subsequent model exploration and optimization.

By converting Equation (13) to a frequency-related formula, we can obtain:

$$
H(f)=\frac{1}{M} \times \frac{(2 \pi f)^{2}\left(\frac{M}{K}\right)}{\sqrt{(2 \pi f)^{2}\left(\frac{M}{K}\right)\left(\frac{C^{2}}{K M}\right)+\left(1-\left(\frac{M}{K}\right)(2 \pi f)^{2}\right)^{2}}}
$$

\subsubsection{The Model Result}

The experimental results have been used for modal parameter identification in accordance with Equation (18), shown in Table 3. 
Table 3. The dynamic properties' changes with flooding level.

\begin{tabular}{ccccccc}
\hline Types of Test & $\begin{array}{c}\text { Flooding } \\
\text { Level }\end{array}$ & $\begin{array}{c}\text { Damping } \\
\text { (kN·s/m) }\end{array}$ & $\begin{array}{c}\text { Stiffness } \\
\text { (MN/m) }\end{array}$ & $\begin{array}{c}\text { Frequency } \\
\text { (Hz) }\end{array}$ & $\begin{array}{c}\text { Curve } \\
\text { Fitting Error }\end{array}$ & $\begin{array}{c}\text { Correlation } \\
\text { Coefficient }\end{array}$ \\
\hline Concrete sleeper & $100 \mathrm{~cm}$ & 1.1626 & 14.6742 & 58 & $0.74 \%$ & $99.26 \%$ \\
on natural ballast & $20 \mathrm{~cm}$ & 1.7753 & 13.7405 & 56 & $0.57 \%$ & $99.43 \%$ \\
$\left(23{ }^{\circ} \mathrm{C}-26{ }^{\circ} \mathrm{C}\right)$ & $30 \mathrm{~cm}$ & 2.8268 & 13.4096 & 56 & $0.45 \%$ & $99.55 \%$ \\
& $35 \mathrm{~cm}$ & 2.3701 & 11.9497 & 52 & $1.56 \%$ & $98.44 \%$ \\
& $40 \mathrm{~cm}$ & 3.3087 & 6.5838 & 31.329 & $0.17 \%$ & $99.83 \%$ \\
& $00 \mathrm{~cm}$ & 1.3239 & 15.0783 & 129 & $1.25 \%$ & $98.75 \%$ \\
\hline FFU sleeper on & $10 \mathrm{~cm}$ & 1.3123 & 15.3719 & 130 & $6.96 \%$ & $93.04 \%$ \\
natural ballast $(21$ & $20 \mathrm{~cm}$ & 1.3859 & 14.8682 & 128 & $0.05 \%$ & $93.85 \%$ \\
$\left.{ }^{\circ} \mathrm{C}-23{ }^{\circ} \mathrm{C}\right)$ & $30 \mathrm{~cm}$ & 1.1585 & 15.0044 & 129 & $2.67 \%$ & $99.95 \%$ \\
& $35 \mathrm{~cm}$ & 1.4073 & 15.0508 & 129 & $0.60 \%$ & $99.33 \%$ \\
& $40 \mathrm{~cm}$ & 6.3001 & 13.1991 & 125 & $0.44 \%$ & $99.56 \%$ \\
\hline Concrete block on & $10 \mathrm{~cm}$ & 1.0815 & 14.2493 & 215 & $3.16 \%$ & $96.84 \%$ \\
natural ballast $(24$ & $20 \mathrm{~cm}$ & 1.1975 & 12.5404 & 210 & $5.00 \%$ & $95.00 \%$ \\
$\left.{ }^{\circ} \mathrm{C}-25{ }^{\circ} \mathrm{C}\right)$ & $30 \mathrm{~cm}$ & 1.3944 & 13.1293 & 202 & $1.47 \%$ & $98.53 \%$ \\
& $35 \mathrm{~cm}$ & 1.6208 & 11.2456 & 192 & $0.93 \%$ & $99.07 \%$ \\
& $40 \mathrm{~cm}$ & 1.2125 & 9.4513 & 176 & $5.62 \%$ & $97.38 \%$ \\
\hline
\end{tabular}

The error of the overall experimental data is relatively minimal, and the curve fitting correlation coefficient rate is basically above $97 \%$ as shown in Figure 14 .

The best curve fitting of the concrete sleeper on the natural ballast

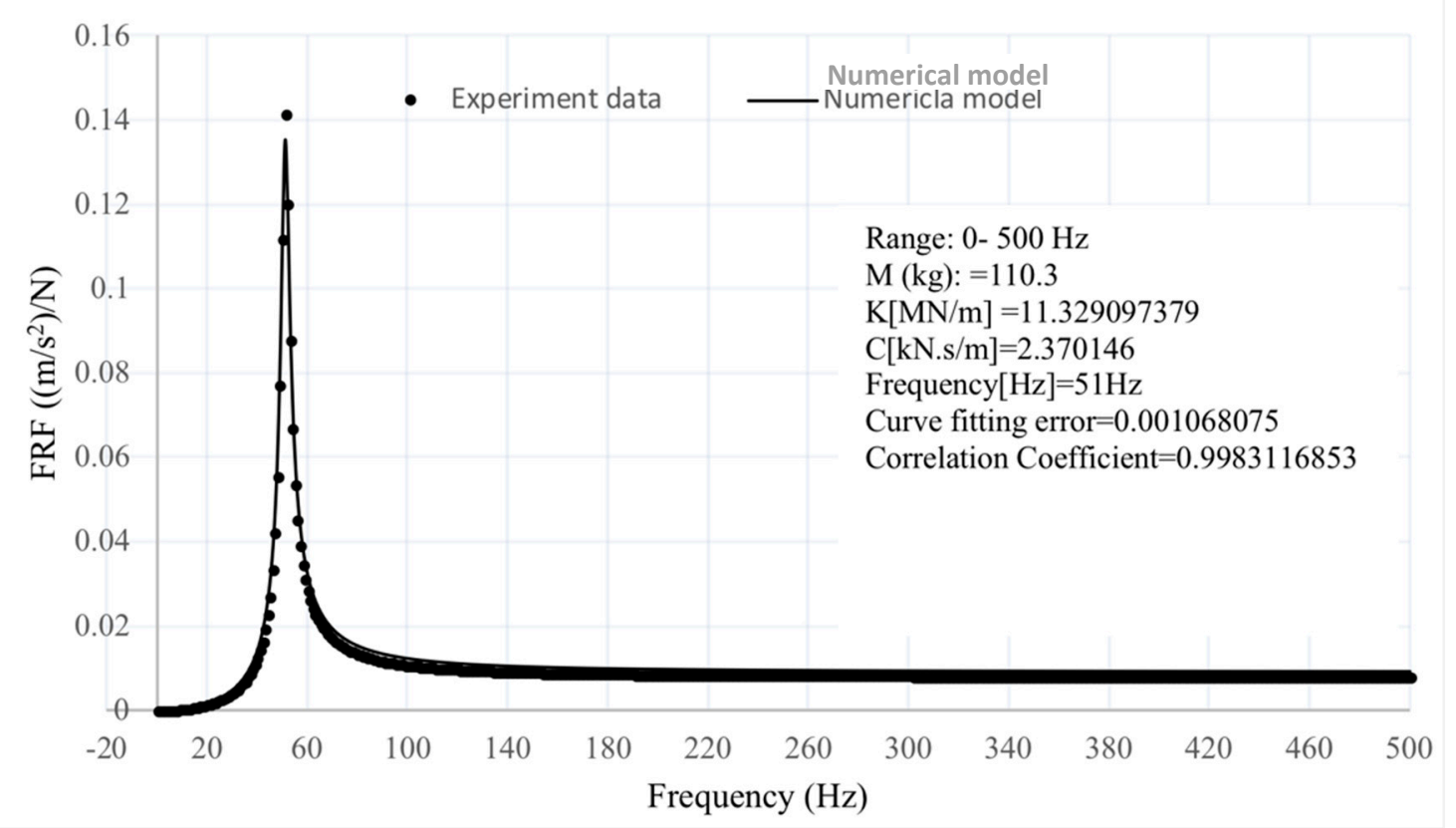

Figure 14. Curve fitting.

\subsubsection{Discussion of Model-1}

The remarks and suitability of the dynamic attributes of ballast can be discussed as follows:

- The Shift of Resonance Frequency

By varying different masses, the frequency interval of the resonant frequency is shifted. Before reaching the full flooding condition (i.e., critical flooding level: $35 \mathrm{~cm}$ ), the respective frequency 
segments are concentrated in the fixed change interval and the deviation is relatively small. After being completely submerged, a significant 'jump' of natural frequencies occurs, which is caused by the bottom surface of the mass coming into contact with flood water, changing the original resonant frequency band irregularly. The second factor is the influence of buoyancy (which will be analysed in a later section): the ballast is soaked in the water and is subjected to upward buoyancy, which induces a significant change in the vibration frequency. Simultaneously, the effective contribution of the dynamic mass will also change. The frequency changes can be illustrated in Figure 15.

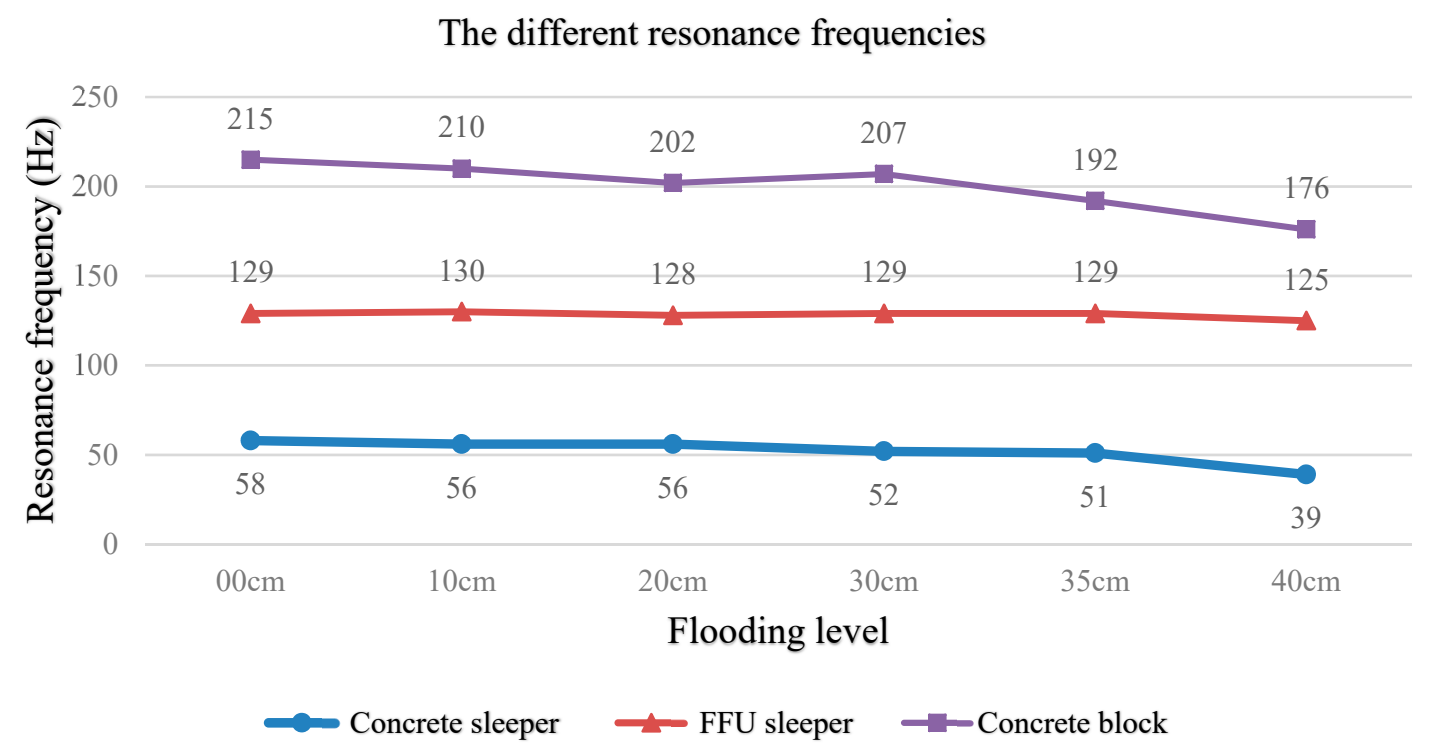

Figure 15. Resonance frequencies.

- The Change of Dynamic Stiffness

Overall, the change of dynamic stiffness is considerable. With the increase in the flood water level, the stiffness will maintain continuous downward trend.

In the dry condition, the stiffness values of the same ballast material are shown to be approximately constant, but are negligibly affected by water temperature (as shown in Table 3). The dynamic stiffness of natural ballast is generally stable at around $15 \mathrm{MN} / \mathrm{m}$.

After experiencing the flood conditions, the change in stiffness depends significantly on the mass level difference. It is clear that the FFU and concrete sleepers exhibit relatively stable dynamic frequencies [39]. Figure 16 illustrates that the FFU sleeper tends to yield slightly higher stiffness of ballast than the others. Note that the ballast specimen is identical. This clearly implies that the track mass plays a key role on the ballast stiffness when flooding conditions occur. It is also clear that, under dry conditions, the track mass does not play an influential role on ballast properties and the discrepancy of dynamic stiffness derived from various test setups is less than $3 \%$.

\subsubsection{The Fixed Relationship between Different Masses}

At resonance, we note that:

$$
\omega=2 \pi f=\omega_{n}=\sqrt{\frac{K}{M}}
$$

Then, the difference in masses imposes the following internal relationship:

$$
\frac{M_{1}}{M_{2}}=\gamma=\frac{K_{1} f_{2}{ }^{2}}{K_{2} f_{1}{ }^{2}}
$$

where 
$\gamma$ : Correlation coefficient of different mass.

M: The effective quality of this system, $7.815 \mathrm{~kg}, 23 \mathrm{~kg}$, and $110.3 \mathrm{~kg}$ respectively.

$K$ : Different dynamic stiffness.

$f$ : The resonant frequency.

The comparison of dynamic stiffness by Model-1

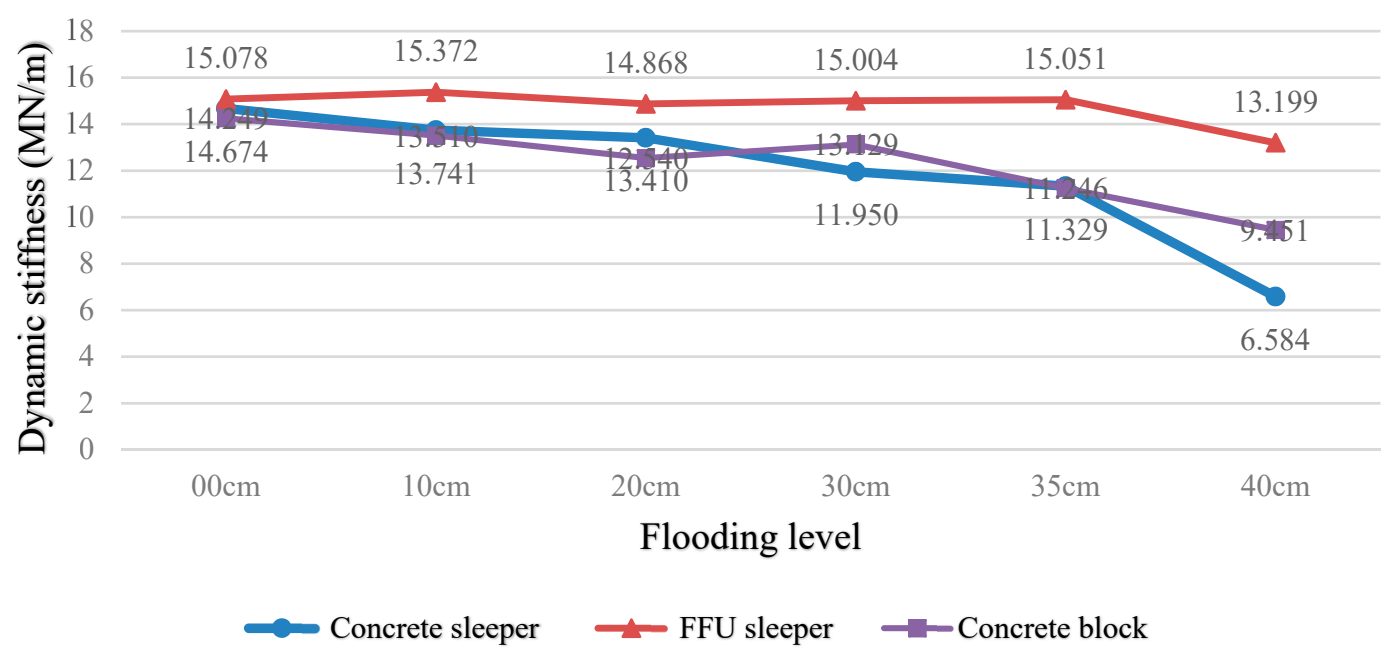

Figure 16. Dynamic stiffness in Model-1.

Based on the relationship between dynamic stiffness and resonance frequency in Figure 17, it should be noted that under the same dynamic stiffness, $\mathrm{M}$ is inversely proportional to $f^{2}$.

The correlation of different masses in the same frequency-stiffness system

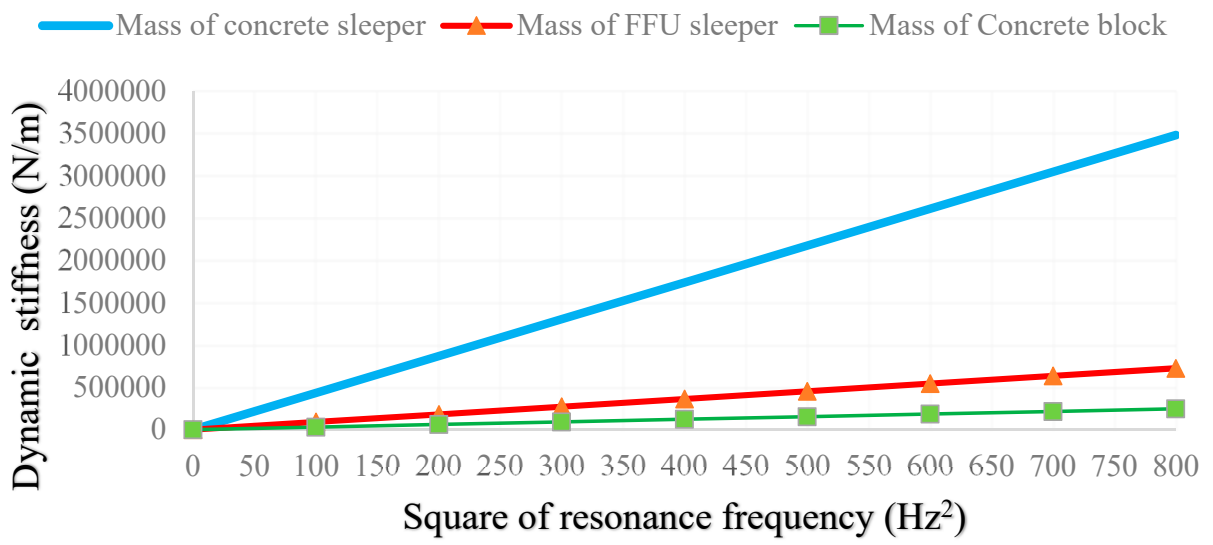

Figure 17. The relationship between dynamic stiffness and resonance frequency squares at different masses.

\subsubsection{The Change of Dynamic Damping}

- Overall, the dynamic damping tends to increase with the increasing flood level as illustrated in Figure 18. In particular, after the ballast is submerged, the damping tends to be affected and probably disturbed by buoyancy. After experiencing the flood environment, the dynamic characteristics of the identical ballast under different masses are different. Although the growth trend continues, the magnitude of the change is rather different. This can be because the water 
buoyancy could indirectly affect frequency changes, which in turn affects the identification of dynamic properties of ballast.

- Under dry conditions, the damping value of the ballast material is constant and is not affected by the difference in masses. The damping of natural ballast is somewhat stable at $1 \mathrm{kN} \cdot \mathrm{s} / \mathrm{m}$.

The comparison of dynamic damping by Model-1

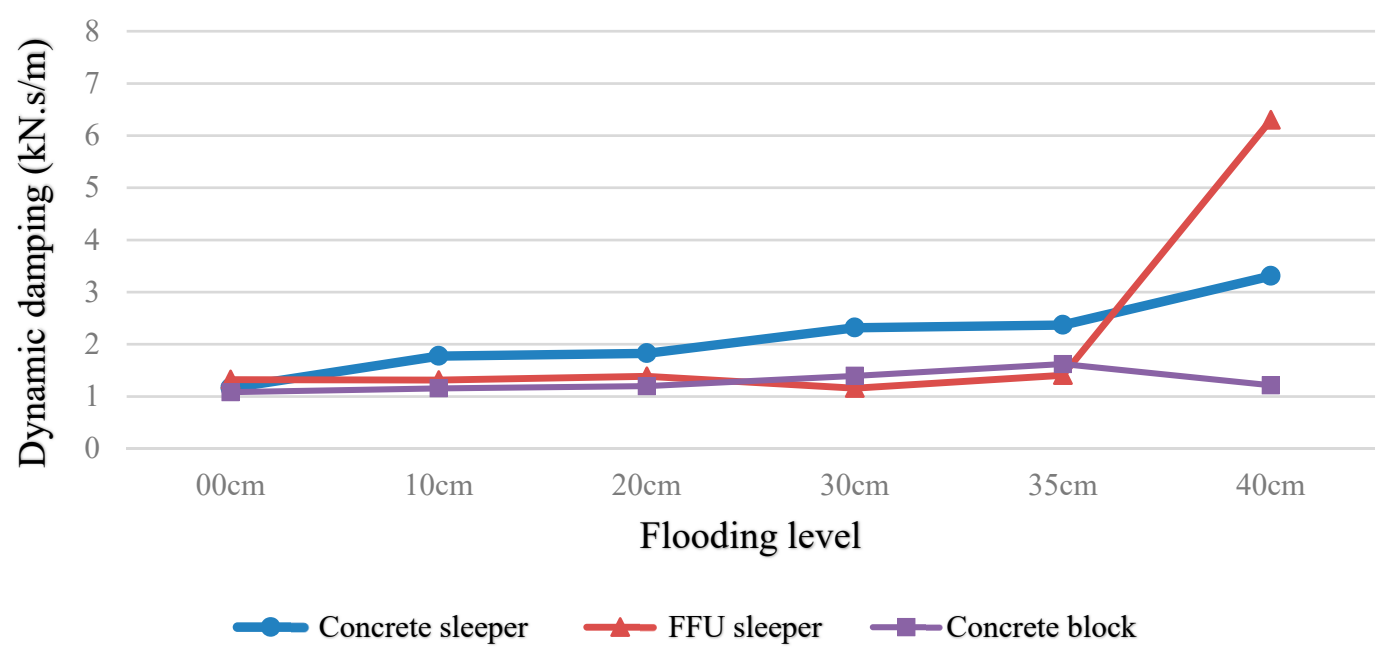

Figure 18. Dynamic damping based on Model-1.

\subsection{Model-2 'KC-C'}

\subsubsection{Model Building}

Model-2 has been derived using a special frequency-dependent damping $C_{1}$, which further modifies the dynamic model of the ballast. The specific model form can be written in Equations (21-23).

$$
M \ddot{X}+C_{2} \dot{X}+\left(\frac{1}{\frac{1}{K}+\frac{1}{C_{1} \omega}}\right) X=F(t)
$$

where $C_{1}, C_{2}$ and $K$ represent the frequency-dependent damping, frequency-independent damping, frequency-independent stiffness of ballast, respectively.

$$
\frac{X_{0}}{F}=\frac{1}{M} \times \frac{1}{\sqrt{\left(\frac{C_{2} \omega}{M}\right)^{2}+\left(\frac{1}{\frac{M}{K}+\frac{M}{C_{1} \omega}}-\omega^{2}\right)^{2}}}
$$

By Fourier series, Equation (23) can be written:

$$
H(f)=\frac{1}{M} \times \frac{(2 \pi f)^{2}\left[M\left(\frac{1}{K}+\frac{1}{2 \pi f C_{1}}\right)\right]}{\sqrt{(2 \pi f)^{2}\left(\frac{M}{K}+\frac{M}{2 \pi f C_{1}}\right) \frac{C_{2}}{M}\left(\frac{1}{K}+\frac{1}{2 \pi f C_{1}}\right)+\left(1-\left(\frac{M}{K}+\frac{M}{2 \pi f C_{1}}\right)(2 \pi f)^{2}\right)^{2}}}
$$

\subsubsection{Model Result}

The modal parameters of ballast based on Model-2 formulation are tabulated in Table 4 as follows: 
Table 4. Dynamic properties of ballast based on Model-2 (using concrete sleeper).

\begin{tabular}{ccccccc}
\hline Water Level & $\mathbf{C}_{\mathbf{1}} \mathbf{( k N \cdot s / m )}$ & $\mathbf{C}_{\mathbf{2}} \mathbf{( k N \cdot s / m )}$ & $\mathbf{K} \mathbf{( M N / m )}$ & $\begin{array}{c}\text { Frequency } \\
\mathbf{( H z )}\end{array}$ & Error & $\begin{array}{c}\text { Correlation } \\
\text { Coefficient }\end{array}$ \\
\hline $00 \mathrm{~cm}$ & $/$ & 1.1626 & 14.6742 & 58 & $0.544 \%$ & $99.456 \%$ \\
$10 \mathrm{~cm}$ & 157246218.0 & 1.7757 & 13.7406 & 56 & $0.401 \%$ & $99.599 \%$ \\
$20 \mathrm{~cm}$ & 8102587.1 & 1.8268 & 13.4097 & 56 & $0.305 \%$ & $99.695 \%$ \\
$30 \mathrm{~cm}$ & 93916878.9 & 2.3175 & 11.9499 & 52 & $1.033 \%$ & $98.967 \%$ \\
$35 \mathrm{~cm}$ & 12062653.1 & 2.3701 & 11.3291 & 51 & $0.107 \%$ & $99.893 \%$ \\
$40 \mathrm{~cm}$ & 90112652.5 & 3.3086 & 6.5844 & 39 & $0.713 \%$ & $99.287 \%$ \\
\hline
\end{tabular}

\subsubsection{Remark of Model-2}

According to Table 4, the best curve-fitting process is similar to that of Model-1. The average error is $0.52 \%$, and the frequency independent damping $C_{2}$ and the dynamic stiffness $K_{1}$ are almost the same as those in Model-1, but the value of damping $C_{1}$ is millions of times larger than usual and exhibits $50 \%$ fluctuations (as shown in Figure 19). Therefore, it can be remarked that this model is not suitable for ballast idealisation.

Frequency-dependent damping $\mathrm{C}_{1}$

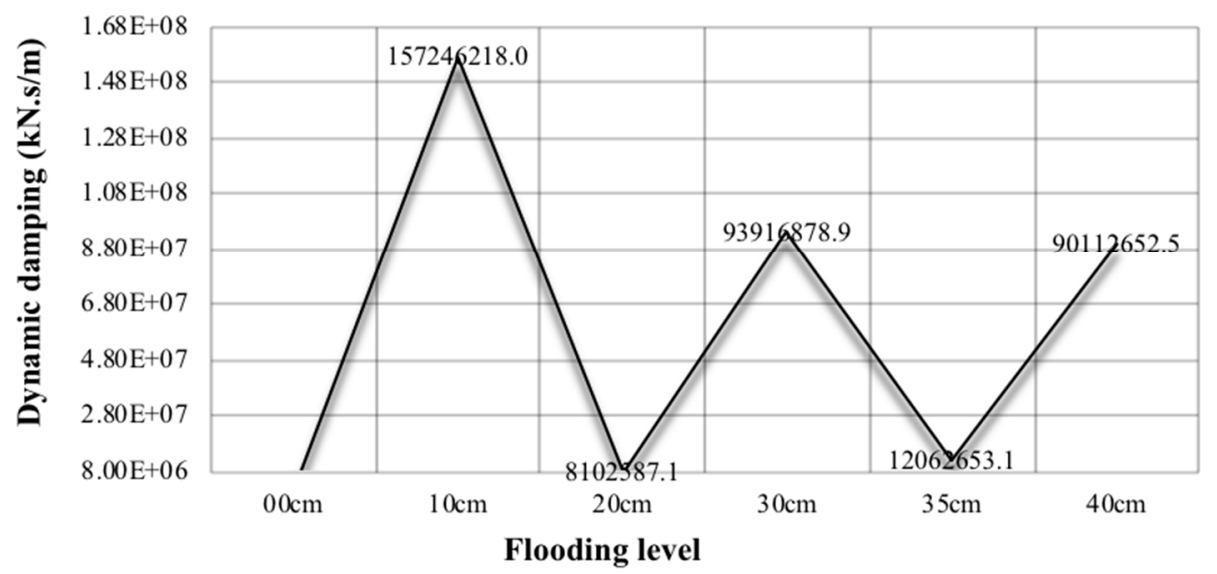

Figure 19. Frequency-dependent damping $C_{1}$.

\subsection{Model-3 'KC-K'}

\subsubsection{Model Building}

Model-3 is aimed to combine the two different levels of stiffness with a damping. This idealisation model can be modified from Equation (14), as follows:

$$
M \ddot{X}+\left(\frac{1}{\frac{1}{C_{1} \omega}-\frac{1}{K_{1}}}\right) X+K_{2} X=F(t)
$$

where $C_{1}, K_{1}$ and $K_{2}$ represent the frequency-dependent damping, frequency-dependent stiffness, and frequency-independent stiffness of ballast, respectively.

$$
H(f)=\frac{1}{M} \times \frac{(2 \pi f)^{2}\left(\frac{M}{K_{2}}\right)}{\sqrt{\left[\frac{\frac{1}{K_{2}{ }^{2}}}{\left(\frac{1}{2 \pi f c}-\frac{1}{K_{1}}\right)}\right]^{2}+\left[1-(2 \pi f)^{2}\left(\frac{M}{K_{2}}\right)\right]^{2}}}
$$


3.4.2. Test Results in Model-3 and Justification

The modal parameters based on Model-3 are shown in Table 5:

Table 5. The dynamic properties of ballast in Model-3.

\begin{tabular}{|c|c|c|c|c|c|c|c|c|}
\hline Types & $\begin{array}{c}\text { Flooding } \\
\text { Level }\end{array}$ & $\begin{array}{c}\text { Damping } \\
\mathrm{C}_{1}(\mathrm{kN} \cdot \mathrm{s} / \mathrm{m})\end{array}$ & $\begin{array}{c}\text { Stiffness } \\
\mathrm{K}_{1}(\mathrm{MN} / \mathrm{m})\end{array}$ & $\begin{array}{c}\text { Stiffness } \\
\mathrm{K}_{2}(\mathrm{MN} / \mathrm{m})\end{array}$ & $\begin{array}{l}\text { Frequency } \\
(\mathbf{H z})\end{array}$ & $\mathbf{R}^{2}$ & $C_{t}$ & $\mathbf{K}_{\mathbf{t}}$ \\
\hline \multirow{6}{*}{$\begin{array}{l}\text { Concrete sleeper } \\
\text { on natural ballast } \\
\left(23^{\circ} \mathrm{C}-26^{\circ} \mathrm{C}\right)\end{array}$} & $00 \mathrm{~cm}$ & 1.1626 & / & 14.6742 & 58 & $99.259 \%$ & 1.16 & 14.67 \\
\hline & $10 \mathrm{~cm}$ & 1.5842 & 5.1906 & 13.7423 & 56 & $99.600 \%$ & 1.76 & 13.80 \\
\hline & $20 \mathrm{~cm}$ & 1.6329 & 5.3604 & 13.4114 & 56 & $99.695 \%$ & 1.81 & 13.47 \\
\hline & $30 \mathrm{~cm}$ & 2.0663 & 6.1864 & 11.9530 & 52 & $98.981 \%$ & 2.29 & 12.03 \\
\hline & $35 \mathrm{~cm}$ & 2.1142 & 6.3562 & 11.3321 & 51 & $99.884 \%$ & 2.34 & 11.40 \\
\hline & $40 \mathrm{~cm}$ & 3.0594 & 9.1594 & 6.5888 & 39 & $99.307 \%$ & 3.29 & 6.65 \\
\hline \multirow{6}{*}{$\begin{array}{c}\text { FFU sleeper on } \\
\text { natural ballast } \\
\left(21^{\circ} \mathrm{C}-23^{\circ} \mathrm{C}\right)\end{array}$} & $00 \mathrm{~cm}$ & 1.3239 & / & 15.0783 & 129 & $93.040 \%$ & 1.32 & 15.08 \\
\hline & $10 \mathrm{~cm}$ & 0.9748 & 3.0967 & 15.3856 & 130 & $95.694 \%$ & 1.23 & 15.58 \\
\hline & $20 \mathrm{~cm}$ & 1.0355 & 3.2988 & 14.8826 & 128 & $99.886 \%$ & 1.30 & 15.08 \\
\hline & $30 \mathrm{~cm}$ & 0.8643 & 2.7483 & 15.0147 & 129 & $98.099 \%$ & 1.09 & 15.18 \\
\hline & $35 \mathrm{~cm}$ & 1.0489 & 3.3429 & 15.0655 & 129 & $99.396 \%$ & 1.32 & 15.27 \\
\hline & $40 \mathrm{~cm}$ & 4.8084 & 16.0920 & 13.5564 & 125 & $99.680 \%$ & 5.97 & 14.40 \\
\hline \multirow{6}{*}{$\begin{array}{c}\text { concrete block on } \\
\text { natural ballast } \\
\left(24^{\circ} \mathrm{C}-25^{\circ} \mathrm{C}\right)\end{array}$} & $00 \mathrm{~cm}$ & 1.0815 & I & 14.2493 & 215 & $96.840 \%$ & 1.08 & 14.25 \\
\hline & $10 \mathrm{~cm}$ & 0.6797 & 2.1809 & 13.5743 & 210 & $93.230 \%$ & 0.99 & 13.89 \\
\hline & $20 \mathrm{~cm}$ & 0.7222 & 2.3210 & 12.6049 & 202 & $94.220 \%$ & 1.04 & 12.92 \\
\hline & $30 \mathrm{~cm}$ & 0.8292 & 2.6763 & 13.2210 & 207 & $93.275 \%$ & 1.20 & 13.59 \\
\hline & $35 \mathrm{~cm}$ & 1.0136 & 3.2896 & 11.3589 & 192 & $92.866 \%$ & 1.42 & 11.76 \\
\hline & $40 \mathrm{~cm}$ & 0.7944 & 2.5542 & 9.5055 & 176 & $93.639 \%$ & 1.08 & 9.78 \\
\hline
\end{tabular}

An example of the best curve fitting can be illustrated in Figure 20.

- The results of all four experiments show that the curve fitting error based on Model-1 is the least compared with those of other models, and the errors are especially higher in smaller-scale experiments.

- Based on Model-3, there is no significant change in frequency-independent stiffness. It can be seen from Figure 21a that the dynamic stiffness traits of the two models are very consistent.

- Figure 21b shows that the variation of the damping in Model-3 displays the same trend as Model-1. This model does not significantly change the original damping, but there is an almost constant gap.

- The frequency-dependent stiffness $K_{1}$ presents a similar variation of damping as shown in Figure 22. The trend is basically consistent with the trend of damping. The combination of spring with the dashpot is a subtractive relationship, so the combination with frequency-independent stiffness will reduce the total stiffness value $\left(\mathrm{K}_{\mathrm{t}}\right)$ of the system.

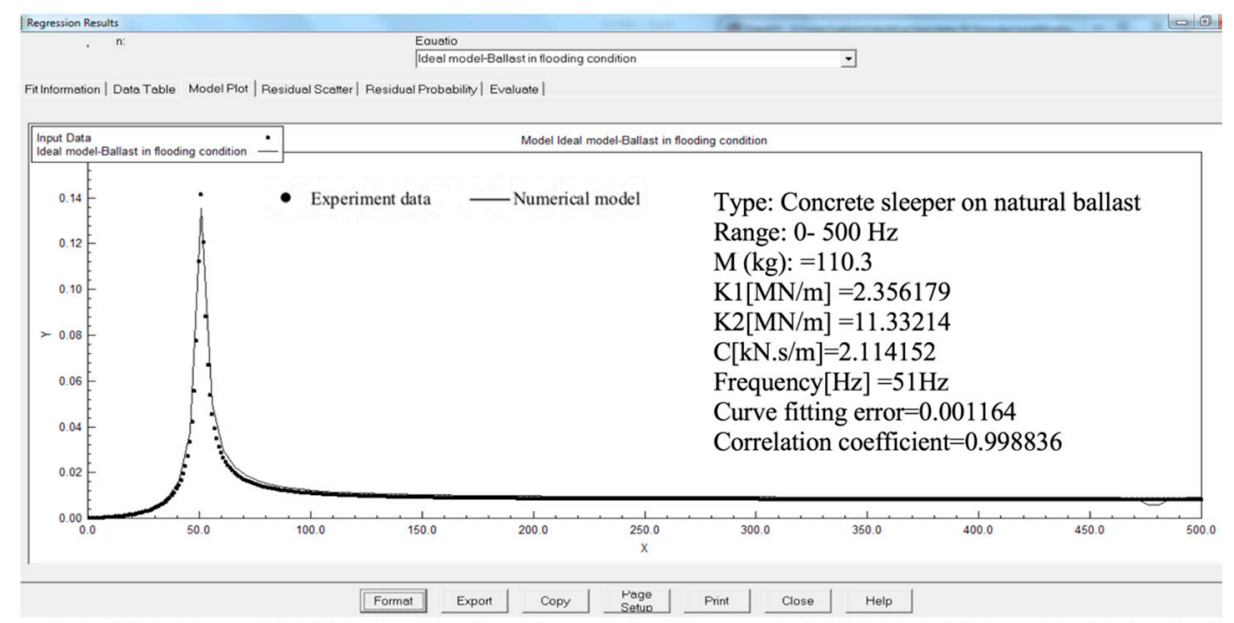

Figure 20. The best curves fitting in Model-3 ( $Y$ axis: FRF; $X$ axis: frequency). 
The stiffness in the two models

(Concrete sleeper)

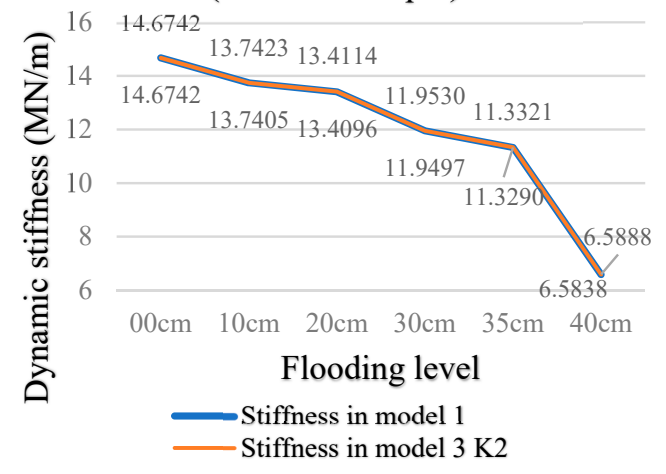

(a)
The damping in the two models

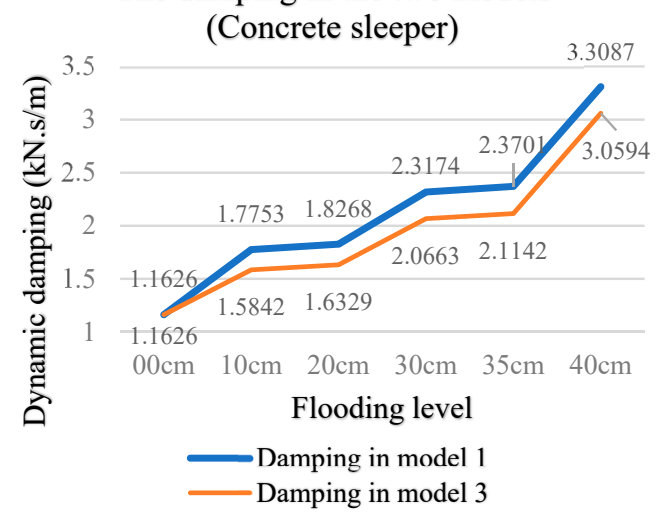

(b)

Figure 21. (a) comparison of dynamic damping at two models; (b) comparison of dynamic stiffness at two models.

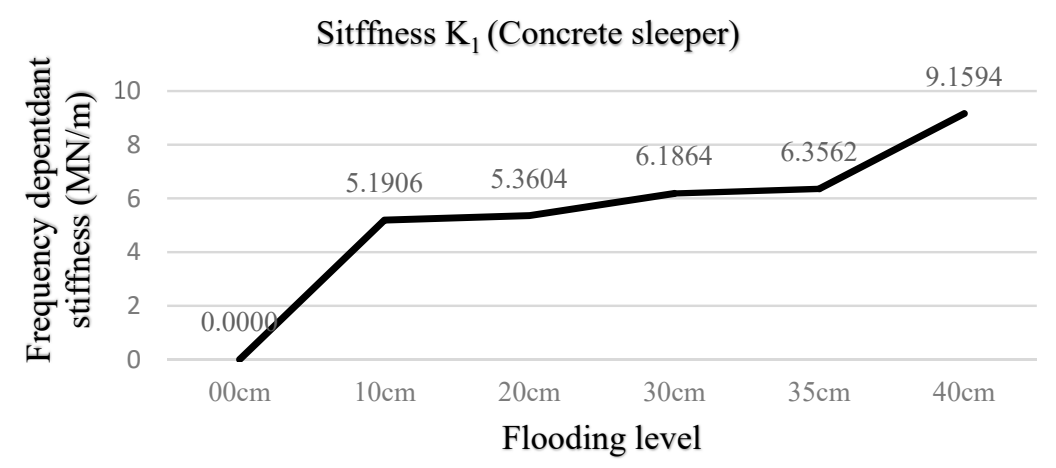

Figure 22. Stiffness $K_{1}$ in Model-3.

\subsubsection{Remark of Model-3}

In this model, the original damping and stiffness are idealised as those in Model-1. In particular, the results thus show that the independent dynamic stiffness values are reasonably stable. When frequency-dependent stiffness is introduced, the change tends to be similar to the dynamic damping.

As described in Model 1, in flood conditions, the dynamic damping and stiffness tested by different kinds of mass can be varied and affected by different frequencies. It is therefore necessary to introduce a frequency-dependent model. Then, another dynamic variable $\mathrm{K}_{1}$ can be introduced in the idealisation model. Compared with Model-1, it is found that $K_{1}$ can slightly reduce the stiffness and damping of the system at the same time.

\subsection{Further Models}

Considering the overall curve fitting errors of Model-3, they are slightly larger than that of Model-1. In order to understand the more detailed dynamic characteristics of the system more clearly and accurately, three more complex models can be further developed based on the dynamic SDOF theory.

\subsubsection{Model-4 'K-KC-C'}

The equation of motion for Model 4 can be rewritten as:

$$
M \ddot{X}+C_{2} \dot{X}+\left(\frac{1}{\frac{1}{K_{1}}+\frac{1}{\omega C_{1}}}\right) X+K_{2} X=F(t)
$$


where $C_{1}, C_{2}$ and $K_{1}, K_{2}$ represent the frequency-dependent damping, frequency-independent damping, and frequency-dependent stiffness, frequency-independent stiffness respectively.

$$
H(\omega)=\frac{X_{0}}{F}=\frac{1}{M} \times \frac{1}{\sqrt{\left(\frac{C_{2} \omega}{M}\right)^{2}+\left(\frac{1}{\frac{M}{K_{1}}+\frac{M}{\omega C_{1}}}\right)^{2}+\left(\frac{K_{2}}{M}-\omega^{2}\right)^{2}}}
$$

The modal parameters based on this model are shown in Figure 23.

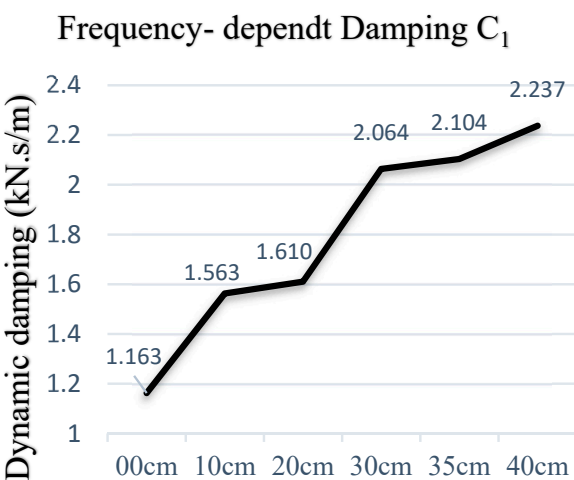

Flooding level

(a)

\section{Frequency-dependent stiffness $\mathrm{K}_{1}$}

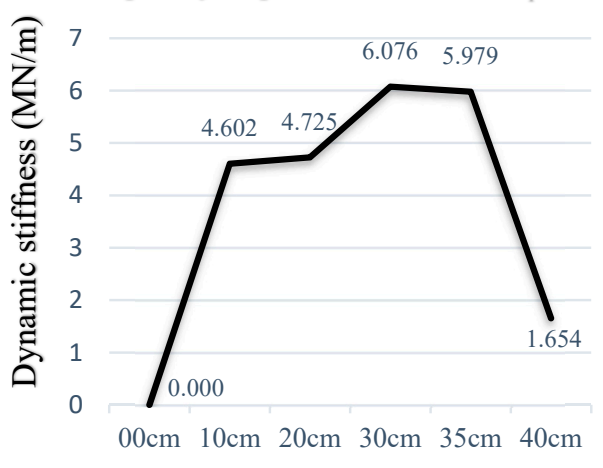

Flooding level

(c)
Frequency-independent Damping $\mathrm{C}_{2}$

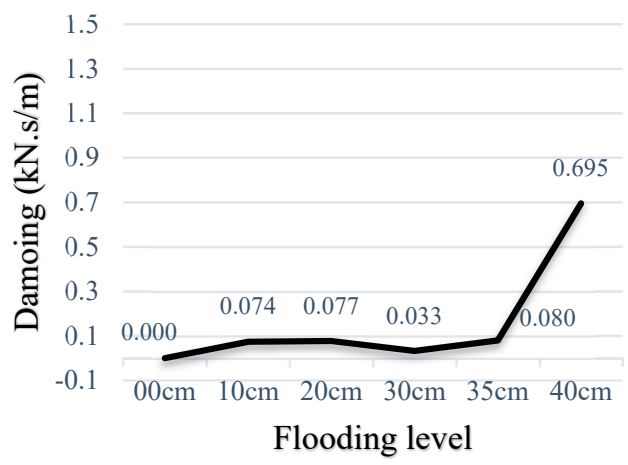

(b)

Frequency-independt stiffness $\mathrm{K}_{2}$

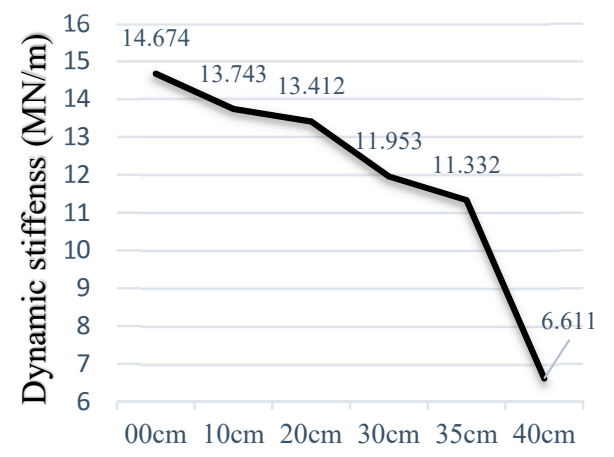

Flooding level

(d)

Figure 23. (a) Frequency-dependent dynamic in Model-4. (b) Frequency-independent dynamic in Model-4. (c) Frequency-dependent stiffness in Model-4. (d) Frequency-independent stiffness in Model-4.

It is found that $C_{1}$ and $K_{2}$ remain the same trends with Model-1 and Model-3, but the trends of $C_{2}$ and $\mathrm{K}_{1}$ can be questionable.

\subsubsection{Model-5 'C-KC-C'}

The equation of motion for Model 5 can be rewritten as:

$$
M \ddot{X}+C_{2} \dot{X}+C_{3} \dot{X}+\left(\frac{1}{\frac{1}{K_{1}}+\frac{1}{\omega C_{1}}}\right) X=F(t)
$$

where $C_{1}, C_{2}, C_{3}$ and $K_{1}$ represent the frequency-dependent, frequency-dependent and frequency-independent damping, frequency-independent stiffness respectively. 


\subsubsection{Model-6 'KC-KC-C'}

The equation of motion for Model 6 can be rewritten as:

$$
M \ddot{X}+C_{3} \dot{X}+\left(\frac{1}{\frac{1}{K_{1}}+\frac{1}{C_{1} \omega}}\right) X+\left(\frac{1}{\frac{1}{K_{2}}+\frac{1}{C_{2} \omega}}\right) X=F(t)
$$

where $C_{1}, C_{2}, C_{3}$ and $K_{1}, K_{2}$ represent the frequency-dependent, frequency-dependent damping, frequency-independent damping and frequency-dependent, frequency-dependent stiffness respectively.

The data analysis of the latter three models shows that the results are more random and inconclusive (similar to the results in Figure 23). On this ground, it can be clear that these models (4-6) might not be suitable for ballast idealisation.

\subsection{Study of Water Buoyancy}

According to the modal analysis, it can be inferred that buoyancy could be a dynamic influential factor, which cannot be ignored in flood conditions. In this study, buoyancy of ballast has been evaluated as shown in Figure 24. The properties of ballast can be listed in Table 6 .

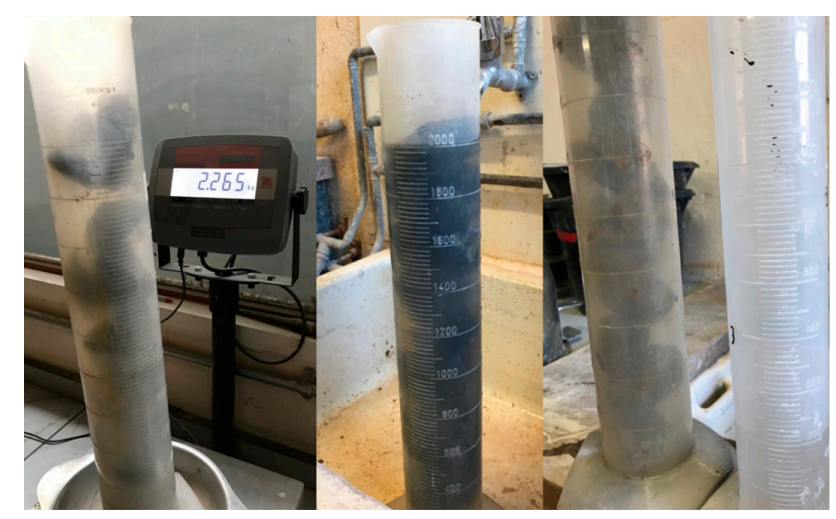

Figure 24. Measurement of displaced water in ballast column.

Table 6. Physical properties of ballast tested in lab.

\begin{tabular}{cccc}
\hline Type of Ballast & $\begin{array}{c}\text { Measured Density } \\
\left(\mathbf{k g} / \mathbf{m}^{\mathbf{3}}\right)\end{array}$ & $\begin{array}{c}\text { The Unit Bulk Weight } \\
\mathbf{( N / \mathbf { m } ^ { 3 } )}\end{array}$ & $\begin{array}{c}\text { Unit Volume of Displaced } \\
\text { Water }\left(\mathbf{m}^{\mathbf{3}} / \mathbf{m}^{\mathbf{3}}\right)\end{array}$ \\
\hline Natural ballast & 1492.806 & 14644.43 & 0.5346 \\
\hline
\end{tabular}

The fundamental method is to measure the volume of water remaining in the container filled with $2000 \mathrm{ml}$ of ballast, thereby obtaining the volume of the displaced water, which is compiled according to the buoyancy formula [42] as follows:

$$
B=\rho_{f} g V_{f}
$$

where

B-buoyancy force in $\mathrm{N}$

$\rho_{f}$-fluid density in $\mathrm{kg} / \mathrm{m}^{3}$

$V_{f}$-displacement volume of water in $\mathrm{m}^{3}$

$g-9.81 \mathrm{~m} / \mathrm{s}^{2}$.

Table 7 shows that water buoyancy is about three times lesser than the self-weight of ballast, confirming that it could potentially cause a small degree of interference to the ballast test results. Note that more detailed data is available in Appendix A. 
Table 7. The water buoyancy by different materials and containers.

\begin{tabular}{cccccc}
\hline Types & Flooding Level & $\begin{array}{c}\text { Volume of } \\
\text { Ballast } \mathbf{( m}^{\mathbf{3}} \text { ) }\end{array}$ & $\begin{array}{c}\text { Volume of } \\
\text { Discharged } \\
\left.\text { Water } \mathbf{( m}^{\mathbf{3}}\right)\end{array}$ & Buoyancy (N) & $\begin{array}{c}\text { Self-Weight } \\
\text { (N) }\end{array}$ \\
\hline Large-scale & $00 \mathrm{~cm}$ & 0.00 & 0.00 & 0.00 & 0 \\
ballast bed & $10 \mathrm{~cm}$ & 0.17 & 0.09 & 873.22 & 2438.30 \\
(natural ballast) & $20 \mathrm{~cm}$ & 0.33 & 0.18 & 1746.44 & 4876.59 \\
& $30 \mathrm{~cm}$ & 0.50 & 0.27 & 2619.67 & 7314.89 \\
& $35 \mathrm{~cm}$ & 0.58 & 0.31 & 3056.28 & 8534.04 \\
& $40 \mathrm{~cm}$ & 0.67 & 0.36 & 3056.28 & 8534.04 \\
\hline Small-scale & $00 \mathrm{~cm}$ & 0.00 & 0.00 & 0.00 & 0.00 \\
ballast bed & $10 \mathrm{~cm}$ & 0.03 & 0.02 & 164.69 & 459.87 \\
(natural ballast) & $20 \mathrm{~cm}$ & 0.06 & 0.03 & 329.39 & 919.74 \\
& $30 \mathrm{~cm}$ & 0.09 & 0.05 & 494.08 & 1379.61 \\
& $35 \mathrm{~cm}$ & 0.11 & 0.06 & 576.42 & 1609.55 \\
\hline
\end{tabular}

\section{Discussion on Suitability of Ballast Idealisation}

\subsection{Introduction to the Railway Ballast}

The majority of railway structures around the world consist of rails mounted onto either wooden or concrete sleepers embedded in ballast, as shown in Figure $25[42,43]$. Their performance significantly depends on the mechanical behaviour of ballast.

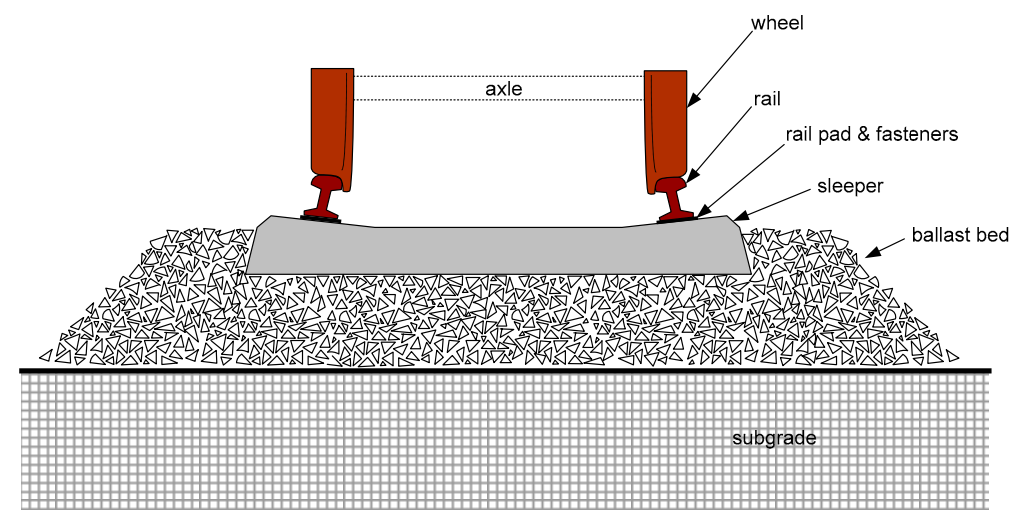

Figure 25. Typical structure of ballast track [42].

Railway ballast can be defined as the selected crushed granular material placed as the top layer of the substructure in which the sleepers are embedded to support the rails [44]. The granular material can provide uniform elastic support for the vertical direction of the rail, which can effectively alleviate the pressure on the subgrade of the bottom of the sleeper. It can provide lateral resistance to ensure that the track and the foundation do not slip. It can also allow the surface water to drain in time etc [45]. The depth of the ballast bed is normally at least $0.3 \mathrm{~m}$ and the width is at least $0.5 \mathrm{~m}$ from the ends of the sleepers [46].

\subsection{Past Investigations into Ballast}

The most common dynamic properties of viscoelastic engineering materials are dynamic stiffness and damping. The idealization of ballast has represented the properties of ballast by using spring and dashpot. Such a method has been adopted for multi-body simulations of train-track interaction in rail industry and has been used for condition monitoring tests in the field and/or in the laboratory.

In the field, Kaewunruen and Remennikov [47] have observed the dynamic characteristics of the ballasted railway track and relevant components. The FRFs [48] were obtained by acquiring the 
resonance frequency range of 0 to $1600 \mathrm{~Hz}$, and the 2 degrees-of-freedom models have been established and analysed for modal parameters [49].

Paixão et al. [50] have studied the sleeper-ballast interaction and refered to the use of special pads such as under sleeper pads to reduce ballast settlement and displacement, thereby saving life cycle costs, numerical modelling and a non-destructuve testing (NDT) technique are discussed. The results showed evidence that USP can increase track flexibility and reduce the full track resonant frequency of about $18 \%$, which suggests influence in track dynamic behaviour. The laboratory simulation experiments are generally used together with preloads because the ballasts are consistently under stress during the train passage [51]. Herron et al. [52] applied the static preload to test elastic materials in tracks, and generate the vibration using the instrumental hammer excitation system to obtain ballast's dynamic properties.

Indraratna et al. [53] have studied the law of deformation and the degradation behaviour of ballast under static and dynamic loads, applying cyclic loads and specific frequencies to simulate high-speed trains, and to measure the settlement and damage of ballast, indicating that the ballast particle size distribution has a significant influence on ballast degradation, and the settlement of ballast stabilizes within 100,000 load cycles. For the environmentally friendly materials, Esmaeili et al. [54] have focused on the mixing of tire-derived aggregates into polymers in different proportions. Under different types of preload dynamic loads, the FRF method is used to calculate the new materials' significant effect of shock absorption and noise reduction, then propose $10 \%$ of tire-derived aggregate is ideal for practical use.

\subsection{Methods in This Study}

\subsubsection{Single-Degree-of-Freedom System}

The idealised single-degree-of-freedom system (SDOF) is a spring-mass-damper system as shown in Figure 26. It contains three elements: stiffness, mass, and the damping coefficient [55] and the properties are mutually independent [56]. The SDOF system is the basis for the study of multi-degree-of-freedom (MDOF) systems. Many of the vibration systems used in today's engineering can be simplified to an SDOF idealisation. This theory can be used to obtain ideal results [57]. A structural SDOF system can be thought of as a single input-single output system [58]. The dynamic characteristics of the system with an independent excitation signal type can be used to optimize the selection of the instrument and the measured structure [59].

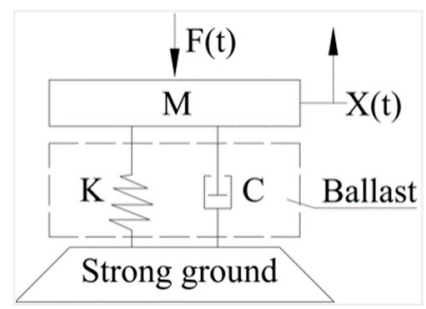

Figure 26. The single-degree-of-freedom (SDOF) idealization.

\subsubsection{Frequency Response Function (FRF)}

The FRF is related to the transfer function. Mathematically, the FRF is defined as the Fourier transformation of the output divided by the Fourier transformation of the input [60].

\subsubsection{The Frequency Domain}

Molodova [61] and Ganesan [62] described the study of the relevant frequency segmentation. It is believed that the corresponding frequencies of the railway structure are mainly concentrated in the mid-domain $40-400 \mathrm{~Hz}$ and in part of the high-domain 400-1500 Hz. Each of the true reflections reflects the persistence of the structure in response to the behaviour of the material itself. Ripke [63] 
has argued that the frequency characteristics of vibration models in other directions are significantly higher than $1500 \mathrm{~Hz}$ which is usually not considered.

\subsection{Research Gap and Problems to Be Resolved}

It is found that only considering the dynamic performance in dry conditions is insufficient as an abnormal climate can occur frequently. The southern Indian state of Kerala just suffered from the worst flood in 100 years [64,65]. Binti et al. [25] has pointed out that the accompanying extreme weather events have grown and are expected to increase in the future. Climate change can cause existing structures to exhibit different performance characteristics than normal [66]. Hence, for the engineering structures, there is a compelling need to consider not only safety and applicability but also reliability, resilience and durability [67].

Until now, most investigations scarcely involve the area of flooded ballast. Kaewunruen [3] has pointed out that it is necessary to determine their railway track exposure and the modal parameters of railway turnouts (switches and crossings) under flood conditions. For a better understanding of mechanical behaviours involving the railway ballast, it requires reasonable test methods and appropriate numerical models [68-71]. Therefore, the study of ballast in flood conditions by identifying the changing law and establishing an ideal dynamic model is particularly important.

This study embarks on the full-scale experiments and formulates 6 models of ballast idealisation concepts. The modal identification results reveal that the fundamental model (Model 1: spring dashpot) prevails over other models in terms of accuracy and precision. The more complicated models (such as Model 2 to 6) are not suitable for ballast idealisation, especially in a flood condition.

\section{Conclusions}

Modern railway tracks have widely adopted railway ballast, which is granular media from crushed rocks, as one of their critical components over centuries. The railway ballast is generally installed under the railway sleeper to align track geometry; absorb dynamic wheel-rail interaction forces; prevent the underlying railway track subgrade from excessive stresses; and enable the interlocking of skeleton track onto the ground providing lateral track stability. Current practices in dynamic coupling vehicle-track simulations idealise track components into MDOF systems. However, to date, only dynamic parameters of dry ballast condition have been investigated. Recent findings show that railway track could significantly experience extreme climate such as long-term flooding. Therefore, it is necessary to identify modal parameters of railway ballast exposed to flooding conditions. This study is the first to highlight such critical conditions. Analytical and experimental studies have been conducted to address such the pressing issue. The modal experimental studies reveal an unprecedented insight into the dynamic properties of the flooded ballast. The flood condition can reduce the stiffness of the track system, whilst also increasing the damping or energy dissipation of the track. It is important to note that this study considered a flash flood case only. In reality, the flood condition can also reduce the load carrying capacity and stiffness of the subgrade layer. In addition, the experiments in this study reveal that a frequency-based condition monitoring technique might have certain limitation in practice. Future work will highlight the development of new SDOF model that is more realistic and more capable of defining state-dependent characteristics of the railway tracks submerged under flood conditions. The influence of impulse energy as well as the track mass will also be investigated in the near future. In summary:

- This research explored the dynamic properties of the railway ballast under various conditions, and identified that their dynamic properties can change significantly under flood conditions compared with a dry state.

- The dynamic modal parameters of the identical ballast material in the dry state are consistently the same regardless of the scale of track masses. Under flood conditions, the resonance frequency shifts are relatively small, the damping increases with the increase of the flooding level, and the stiffness 
exhibits a decreasing trend. This phenomenon is especially obvious when the conventional concrete sleeper is used for testing the natural ballast.

- The changes in water temperature can slightly affect the test results, high temperature can decrease the dynamic stiffness, and low temperature can increase the dynamic stiffness, then the resonance frequency will change as well.

- The correlation between different masses has a proportional relationship to their dynamic stiffness divided by the square of the natural frequency.

- The small mass resonance frequency occurs in the high-frequency band, and the larger resonance occurs in the low-frequency band. The experimental results show that the low-frequency band data is more accurate.

- The increase in the flooding level will change natural frequency and decrease the FRF. The system stiffness will decrease with the decrease of the natural frequency.

- The properties of the material have different effects on the dynamic characteristics of the study. Meanwhile, the buoyancy will also have an interference effect on the system, especially where the test is conducted by using a lighter track mass.

- In order to obtain data for the experiment, a total of six dynamic models were established for this study, and the first three were discussed in detail, among which two reasonable models (Models 1 and 3) were found. The mean values of the experimental data curve fittings in Model-1 and Model-3 were $97.45 \%$ and $96.95 \%$, respectively. The state-dependent model (Model 3) is found to be reasonable but needs further optimisation.

- This experiment is the world's first investigation into railway ballast behaviour in flood conditions. The insights into modal parameters and idealisation of ballast in flood conditions provide a new reference for the numerical train-track simulations in practice.

Author Contributions: Conceptualization, S.K. and T.T.; Methodology, S.K. and T.T.; Validation, S.K.; Formal Analysis, T.T.; Investigation, S.K. and T.T.; Resources, S.K.; Writing-Original Draft Preparation, T.T. and S.K.; Writing-Review and Editing, S.K. and; Visualization, T.T.; Supervision, S.K.; Funding Acquisition, S.K.

Funding: This project has received funding from the European Union's Horizon 2020 research and innovation programme under the Marie Skłodowska-Curie grant agreement No 691135 “RISEN: Rail Infrastructure Systems Engineering Network". The APC has been sponsored by the University of Birmingham Library's Open Access Fund.

Acknowledgments: The first author wishes to gratefully acknowledge the Japan Society for Promotion of Science (JSPS) for his JSPS Invitation Research Fellowship (Long-term), Grant No L15701, at the Track Dynamics Laboratory, Railway Technical Research Institute and at Concrete Laboratory, the University of Tokyo, Tokyo, Japan. The JSPS financially supports this work as part of the research project, entitled "Smart and reliable railway infrastructure". Special thanks to European Commission for H2020-MSCA-RISE Project No. 691135 "RISEN: Rail Infrastructure Systems Engineering Net-work" (www.risen2rail.eu) [72]. In addition, the sponsorships and assistance from CEMEX, Network Rail, RSSB (Rail Safety and Standard Board, UK) are highly appreciated. Financial support from BRIDGE Grant (Collaboration between University of Birmingham and University of Illinois at Urbana Champaign) is also gratefully acknowledged. Technical advice from Miquel Morata (Comsa, Spain) is appreciated.

Conflicts of Interest: The authors declare no conflict of interest. 


\section{Appendix A}

Table A1. Comparison of the dynamic properties of railway ballast in flood.

\begin{tabular}{|c|c|c|c|c|c|c|c|c|c|c|c|c|}
\hline \multirow[b]{2}{*}{ Types } & \multirow[b]{2}{*}{$\begin{array}{c}\text { Flooding } \\
\text { Level }\end{array}$} & \multirow[b]{2}{*}{$\begin{array}{l}\text { Resonant } \\
\text { Frequency } \\
\text { (Hz) }\end{array}$} & \multicolumn{3}{|c|}{ Model 1} & \multicolumn{7}{|c|}{ Model 3} \\
\hline & & & $\begin{array}{l}\text { Damping } \\
(\mathrm{kN} \cdot \mathrm{s} / \mathrm{m})\end{array}$ & $\begin{array}{l}\text { Stiffness } \\
(\mathrm{MN} / \mathrm{m})\end{array}$ & $\begin{array}{l}\text { Correlation } \\
\text { Coefficient }\end{array}$ & $\begin{array}{l}\text { Damping } \\
(\mathrm{kN} \cdot \mathrm{s} / \mathrm{m})\end{array}$ & $\begin{array}{l}\text { Frequency- } \\
\text { Dependent } \\
K_{1}(M N / m)\end{array}$ & $\begin{array}{c}\text { Frequency- } \\
\text { Independent } \\
\mathrm{K}_{2}(\mathrm{MN} / \mathrm{m})\end{array}$ & $\begin{array}{l}\text { Correlation } \\
\text { Coefficient }\end{array}$ & $\begin{array}{c}\text { Total } \\
\text { Damping } \\
\mathrm{C}_{\mathrm{t}}(\mathrm{kN} \cdot \mathrm{s} / \mathrm{m})\end{array}$ & $\begin{array}{c}\text { Total } \\
\text { Stiffness } K_{t} \\
(\mathrm{MN} / \mathrm{m})\end{array}$ & $\begin{array}{c}\text { Damping } \\
\text { Ratio } \zeta\end{array}$ \\
\hline \multirow{6}{*}{$\begin{array}{c}\text { concrete } \\
\text { sleeper on } \\
\text { natural ballast } \\
\left(23^{\circ} \mathrm{C}-26^{\circ} \mathrm{C}\right)\end{array}$} & $00 \mathrm{~cm}$ & 58 & 1.163 & 14.674 & $99.26 \%$ & 1.020 & 0.000 & 14.674 & $99.26 \%$ & 1.163 & 14.674 & 0.01 \\
\hline & $10 \mathrm{~cm}$ & 56 & 1.775 & 13.741 & $99.43 \%$ & 1.584 & 5.191 & 13.742 & $99.60 \%$ & 1.755 & 13.683 & 0.02 \\
\hline & $20 \mathrm{~cm}$ & 56 & 1.827 & 13.410 & $99.55 \%$ & 1.633 & 5.360 & 13.411 & $99.70 \%$ & 1.806 & 13.351 & 0.02 \\
\hline & $30 \mathrm{~cm}$ & 52 & 2.317 & 11.950 & $98.44 \%$ & 2.066 & 6.186 & 11.953 & $98.98 \%$ & 2.290 & 11.880 & 0.03 \\
\hline & $35 \mathrm{~cm}$ & 51 & 2.370 & 11.329 & $99.83 \%$ & 2.114 & 6.356 & 11.332 & $99.88 \%$ & 2.344 & 11.261 & 0.03 \\
\hline & $40 \mathrm{~cm}$ & 39 & 3.309 & 6.584 & $98.75 \%$ & 3.059 & 9.159 & 6.589 & $99.31 \%$ & 3.287 & 6.528 & 0.06 \\
\hline \multirow{6}{*}{$\begin{array}{c}\text { FFU sleeper } \\
\text { on natural } \\
\text { ballast } \\
\left(21^{\circ} \mathrm{C}-23^{\circ} \mathrm{C}\right)\end{array}$} & $00 \mathrm{~cm}$ & 129 & 1.324 & 15.078 & $93.04 \%$ & 1.324 & 0.000 & 15.078 & $93.04 \%$ & 1.324 & 15.078 & 0.04 \\
\hline & $10 \mathrm{~cm}$ & 130 & 1.312 & 15.372 & $93.85 \%$ & 0.975 & 3.097 & 15.386 & $95.69 \%$ & 1.231 & 15.194 & 0.03 \\
\hline & $20 \mathrm{~cm}$ & 128 & 1.386 & 14.868 & $99.95 \%$ & 1.036 & 3.299 & 14.883 & $99.89 \%$ & 1.303 & 14.685 & 0.04 \\
\hline & $30 \mathrm{~cm}$ & 129 & 1.158 & 15.004 & $97.33 \%$ & 0.864 & 2.748 & 15.015 & $98.10 \%$ & 1.088 & 14.847 & 0.03 \\
\hline & $35 \mathrm{~cm}$ & 129 & 1.407 & 15.051 & $99.40 \%$ & 1.049 & 3.343 & 15.065 & $99.40 \%$ & 1.322 & 14.862 & 0.04 \\
\hline & $40 \mathrm{~cm}$ & 125 & 6.300 & 13.199 & $99.56 \%$ & 4.808 & 16.092 & 13.556 & $99.68 \%$ & 5.971 & 12.716 & 0.17 \\
\hline
\end{tabular}

Table A2. Comparison of the dynamic properties of railway ballast in flood.

\begin{tabular}{|c|c|c|c|c|c|c|c|c|c|c|c|c|}
\hline \multirow[b]{2}{*}{ Types } & \multirow[b]{2}{*}{$\begin{array}{l}\text { Flooding } \\
\text { Level }\end{array}$} & \multirow[b]{2}{*}{$\begin{array}{l}\text { Resonant } \\
\text { Frequency } \\
\text { (Hz) }\end{array}$} & \multicolumn{3}{|c|}{ Model 1} & \multicolumn{7}{|c|}{ Model 3} \\
\hline & & & $\begin{array}{l}\text { Damping } \\
(\mathbf{k N} \cdot \mathrm{s} / \mathrm{m})\end{array}$ & $\begin{array}{l}\text { Stiffness } \\
(\mathrm{MN} / \mathrm{m})\end{array}$ & $\begin{array}{l}\text { Correlation } \\
\text { Coefficient }\end{array}$ & $\begin{array}{l}\text { Damping } \\
(\mathbf{k N} \cdot \mathrm{s} / \mathrm{m})\end{array}$ & $\begin{array}{l}\text { Frequency- } \\
\text { Dependent } \\
\mathrm{K}_{1}(\mathrm{MN} / \mathrm{m})\end{array}$ & $\begin{array}{c}\text { Frequency- } \\
\text { Independent } \\
K_{2}(\mathrm{MN} / \mathrm{m})\end{array}$ & $\begin{array}{l}\text { Correlation } \\
\text { Coefficient }\end{array}$ & $\begin{array}{c}\text { Total } \\
\text { Damping } \\
\mathrm{C}_{\mathrm{t}}(\mathrm{kN} \cdot \mathrm{s} / \mathrm{m})\end{array}$ & $\begin{array}{c}\text { Total } \\
\text { Stiffness } \mathrm{K}_{\mathrm{t}} \\
(\mathrm{MN} / \mathrm{m})\end{array}$ & $\begin{array}{c}\text { Damping } \\
\text { Ratio } \zeta\end{array}$ \\
\hline \multirow{6}{*}{$\begin{array}{c}\text { concrete block } \\
\text { on natural } \\
\text { ballast } \\
\left(24^{\circ} \mathrm{C}-25^{\circ} \mathrm{C}\right)\end{array}$} & $00 \mathrm{~cm}$ & 215 & 1.082 & 14.249 & $96.84 \%$ & 1.082 & 0.000 & 14.249 & $96.84 \%$ & 1.082 & 14.249 & 0.05 \\
\hline & $10 \mathrm{~cm}$ & 210 & 1.156 & 13.510 & $95.00 \%$ & 0.680 & 2.181 & 13.574 & $93.23 \%$ & 0.989 & 13.259 & 0.05 \\
\hline & $20 \mathrm{~cm}$ & 202 & 1.197 & 12.540 & $98.53 \%$ & 0.722 & 2.321 & 12.605 & $94.22 \%$ & 1.036 & 12.292 & 0.05 \\
\hline & $30 \mathrm{~cm}$ & 207 & 1.394 & 13.129 & $99.07 \%$ & 0.829 & 2.676 & 13.221 & $93.28 \%$ & 1.200 & 12.847 & 0.06 \\
\hline & $35 \mathrm{~cm}$ & 192 & 1.621 & 11.246 & $97.38 \%$ & 1.014 & 3.290 & 11.359 & $92.87 \%$ & 1.424 & 10.960 & 0.08 \\
\hline & $40 \mathrm{~cm}$ & 176 & 1.213 & 9.451 & $94.87 \%$ & 0.794 & 2.554 & 9.506 & $93.64 \%$ & 1.084 & 9.235 & 0.06 \\
\hline
\end{tabular}




\section{References}

1. Esveld, C. Modern Railway Track, 2nd ed.; MRT-Productions Press: Groenwal, The Netherlands, $2001 ;$ p. 653.

2. Indraratna, B.; Rujikiatkamjorn, C.; Salim, W. Advanced Rail Geotechnology_Ballasted Track; CRC Press: London, UK, 2011.

3. Kaewunruen, S. Ballast and Ballast Mat, Rail Engineering Course Topic 2.8; RailCorp NSW: Sydney, Australia, 2012; pp. 1-13.

4. Kaewunruen, S.; Remennikov, A.M. Non-Destructive Testing (NDT): A Tool for Dynamic Health Monitoring of Railway Track Structures; Materials Australia: North Melbourne, Australia, 2006; Volume 39, pp. 14-16.

5. Remennikov, A.M.; Kaewunruen, S. A review on loading conditions for railway track structures due to train and track vertical interaction. Struct. Control Health Monit. 2008, 15, 207-234. [CrossRef]

6. Kaewunruen, S.; Remennikov, A.M. Experimental simulation of the railway ballast by resilient materials and its verification by modal testing. Exp. Tech. 2008, 32, 29-35. [CrossRef]

7. Kaewunruen, S.; Remennikov, A.M. Nonlinear finite element modeling of railway prestressed concrete sleeper. In Proceedings of the 10th East Asia-Pacific Conference on Structural Engineering and Construction, EASEC 2010, Bangkok, Thailand, 3-5 August 2006; Volume 4, pp. 323-328.

8. Vu, M.; Kaewunruen, S.; Attard, M. Nonlinear 3D finite-element modeling for structural failure analysis of concrete sleepers/bearers at an urban turnout diamond. In Handbook of Materials Failure Analysis with Case Studies from the Chemicals, Concrete and Power Industries; Elsevier: Amsterdam, The Netherlands, 2016; Chapter 6; pp. 123-160. Available online: http://dx.doi.org/10.1016/B978-0-08-100116-5.00006-5 (accessed on 26 April 2019).

9. Remennikov, A.M.; Murray, M.H.; Kaewunruen, S. Reliability-based conversion of a structural design code for railway prestressed concrete sleepers. Proc. Inst. Mech. Eng. Part F J. Rail Rapid Transit 2012, 226, 155-173. [CrossRef]

10. Kaewunruen, S.; Ishida, T.; Remennikov, A.M. Dynamic performance of concrete turnout bearers and sleepers in Railway Switches and Crossings. Adv. Civ. Eng. Mater. 2018, 7. [CrossRef]

11. AREMA. AREMA-Manual for Railway Engineering; American Railway Engineering and Maintenance-of-Way Association: Lanham, MD, USA, 2012; Chapter 30.

12. Kaewunruen, S.; Remennikov, A.M. Sensitivity analysis of free vibration characteristics of an in-situ railway concrete sleeper to variations of rail pad parameters. J. Sound Vib. 2006, 298, 453-461. [CrossRef]

13. Kaewunruen, S.; Kimani, S.K. Damped frequencies of precast modular steel-concrete composite railway track slabs. Steel Compos. Struct. 2017, 25, 427-442.

14. Kimani, S.K.; Kaewunruen, S. Free vibrations of precast modular steel-concrete composite railway track slabs. Steel Compos. Struct. Int. J. 2017, 24, 113-128. [CrossRef]

15. Kaewunruen, S.; Remennikov, A.M. State dependent properties of rail pads. Transp. Eng. Aust. 2009, 12, 17-24.

16. Gamage, E.K.; Kaewunruen, S.; Remennikov, A.M.; Ishida, T. Toughness of Railroad Concrete Crossties with Holes and Web Openings. Infrastructures 2017, 2, 3. [CrossRef]

17. Gamage, E.K.; Kaewunruen, S.; Remennikov, A.M.; Ishida, T. Reply to Giannakos, K. Comment on: Toughness of Railroad Concrete Crossties with Holes and Web Openings. Infrastructures 2017, 2, 5.

18. Kaewunruen, S.; Lopes, L.M.C.; Papaelias, M.P. Georisks in railway systems under climate uncertainties by different types of sleeper/crosstie materials. Lowl. Technol. Int. 2018, 20, 67-76.

19. Binti Sa'adin, S.L.; Kaewunruen, S.; Jaroszweski, D. Risks of Climate Change with Respect to the Singapore-Malaysia High Speed Rail System. Climate 2016, 4, 65. [CrossRef]

20. Binti Sa'adin, S.L.; Kaewunruen, S.; Jaroszweski, D. Heavy rainfall and flood vulnerability of Singapore-Malaysia high speed rail system. Aust. J. Civ. Eng. 2016, 14, 123-131. [CrossRef]

21. Binti Sa'adin, S.L.; Kaewunruen, S.; Jaroszweski, D. Operational readiness for climate change of Malaysia high-speed rail. Proc. Inst. Civ. Eng. Transp. 2016, 169, 308-320. [CrossRef]

22. Dindar, S.; Kaewunruen, S.; Min, A.; Sussman, J.M. Bayesian Network-based probability analysis of train derailments caused by various extreme weather patterns on railway turnouts. Saf. Sci. 2018, 110, 20-30. [CrossRef]

23. Ngamkhanong, C.; Kaewunruen, S.; Costa, B.J.A. State-of-the-Art Review of Railway Track Resilience Monitoring. Infrastructures 2018, 3, 3. [CrossRef] 
24. Kaewunruen, S.; Wu, L.; Goto, K.; Najih, Y.M. Vulnerability of Structural Concrete to Extreme Climate Variances. Climate 2018, 6, 40. [CrossRef]

25. Binti Sa'adin, S.L.; Kaewunruen, S.; Jaroszweski, D. Climate change vulnerability and adaptation for the Singapore-Malaysia high speed rail system. INGENIEUR-Off. J. Board Eng. Malays. 2016, 66, 44-54.

26. Dindar, S.; Kaewunruen, S.; An, M.; Osman, M.H. Natural hazard risks on railway turnout systems. Procedia Eng. 2016, 161, 1254-1259. [CrossRef]

27. Kaewunruen, S. Impact Damage Mechanism and Mitigation by Ballast Bonding at Railway Bridge Ends. Int. J. Railw. Technol. 2014, 3, 1-22. [CrossRef]

28. De Man, A.P. DYNATRACK: A survey of dynamic railway track properties and their quality. Ph.D. Thesis, Faculty of Civil Engineering, Delft University of Technology, Delft, The Netherlands, 2002.

29. Fenander, A. A fractional derivative railpad model included in a railway track model. J. Sound Vib. 1998, 212, 889-903. [CrossRef]

30. Cai, Z. Modelling of rail track dynamics and wheel/rail interaction. Ph.D. Thesis, Department of Civil Engineering, Queen's University, Kingston, ON, Canada, 1992.

31. Kaewunruen, S.; Remennikov, A.M. Effect of improper ballast tamping/packing on dynamic behaviors of on-track railway concrete sleeper. Int. J. Struct. Stab. Dyn. 2007, 7, 167-177. [CrossRef]

32. Kaewunruen, S.; Remennikov, A.M. Current state of practice in railway track vibration isolation: An Australian overview. Aust. J. Civ. Eng. 2016, 14, 63-71. [CrossRef]

33. Remennikov, A.M.; Kaewunruen, S. Impact resistance of reinforced concrete columns: Experimental studies and design considerations. In Proceedings of the 19th Australasian Conference on the Mechanics of Structures and Materials, ACMSM19, Christchurch, New Zealand, 29 November-1 December 2006.

34. FFU. Synthetic Wood Railway Sleepers. 2019. Available online: https://www.sekisui-rail.com/en/technology. html (accessed on 1 April 2019).

35. Prosig. Manual on Experimental Model Analysis Using Impact Hammer Excitation; Prosig Ltd.: Southfield, MI, USA, 2017.

36. Remennikov, A.; Kaewunruen, S. Determination of Dynamic properties of rail pads using an instrumented hammer impact technique. Acoust. Aust. 2005, 33, 63-67.

37. Kaewunruen, S.; Remennikov, A. Application of Experimental Modal Testing for Estimating Dynamic Properties of Structural Components. In Proceedings of the Australian Structural Engineering Conference 2005 (ASEC 2005), Newcastle, Australia, 1-14 September 2005.

38. Kaewunruen, S.; Remennikov, A.M. An alternative rail pad tester for measuring dynamic properties of rail pads under large preloads. Exp. Mech. 2008, 48, 55-64. [CrossRef]

39. Rasmussen, S.; De Man, A. Two new techniques for measurement of vertical track stiffness of railway tracks. In Proceedings of the 3rd International Railway Engineering Conference, Edinburg, Scotland, UK, 3-4 July 2000.

40. Kaewunruen, S. Monitoring in-service performance of fibre-reinforced foamed urethane sleepers/bearers in railway urban turnout systems. Struct. Mor. Main. 2014, 1, 131-157. [CrossRef]

41. Kaewunruen, S.; Remennikov, A. Dynamic Properties of Railway Track and Its Components: A State-of-the-Art Review; University of Wollongong: New South Wales, Australia, 2008.

42. Van't Zand, J. Assessment of dynamic characteristics of rail pads. Rail Eng. Int. 1994, 23, 15-17.

43. Rezaei, E. Vibrations of Partly Supported Concrete Railway Sleeper. Master's Thesis, Department of Management and Engineering, Linköping University, Linköping, Sweden, 2010.

44. Ripke, B.; Knothe, K. Simulation of high frequency vehicle-track interactions. Veh. Syst. Dyn. 1995, 24 (Suppl. 1), 72-85. [CrossRef]

45. Indraratna, B.; Khabbaz, H.; Salim, W.; Christie, D. Geotechnical properties of ballast and the role of geosynthetics. In Institution of Civil Engineers. Proceedings. Ground 3; ICE Publishing: London, UK, 2006.

46. Indraratna, B.; Salim, W.; Rujikiatkamjorn, C. Advanced Rail Geotechnology-Ballasted Track; CRC Press: Boca Raton, FL, USA, 2011.

47. Civilstagram. Track Ballast. Available online: http://civilstagram.blogspot.com/2016/02/track-ballast.html\# (accessed on 25 February 2016).

48. Witt, S. The Influence of under Sleeper Pads on Railway Track Dynamics. Master's Thesis, Department of Management and Engineering, Linköping University, Linköping, Sweden, 2008. 
49. Kaewunruen, S.; Remennikov, A. Field trials for dynamic characteristics of railway track and its components using impact excitation technique. NDT E Int. 2007, 40, 510-519. [CrossRef]

50. Peeters, B.; Van der Auweraer, H.; Guillaume, P.; Leuridan, J. The PolyMAX frequency-domain method: A new standard for modal parameter estimation. Shock Vib. 2004, 11, 395-409. [CrossRef]

51. Datafit. User's Manual; Oakdale Engineering: Oakdale, PA, USA, 2006.

52. Paixão, A.; Alves Ribeiro, C.; Pinto, N.; Fortunato, E.; Calçada, R. On the use of under sleeper pads in transition zones at railway underpasses: Experimental field testing. Struct. Infrastruct. Eng. 2015, 11, 112-128. [CrossRef]

53. Powrie, W.; Yang, L.A.; Clayton, C.R. Stress changes in the ground below ballasted railway track during train passage. Proc. Inst. Mech. Eng. Part F J. Rail Rapid Transit 2007, 221, 247-262. [CrossRef]

54. Herron, D.; Jones, C.; Thompson, D.; Rhodes, D. Characterising the high-frequency dynamic stiffness of railway ballast. In Proceedings of the 16th International Congress on Sound and Vibration: Recent Developments in Acoustics (Noise and Vibration (ICSV16)), Krakow, Poland, 5-9 July 2009; pp. 5-9.

55. Esmaeili, M.; Aela, P.; Hosseini, A. Experimental assessment of cyclic behaviour of sand-fouled ballast mixed with tire derived aggregates. Soil Dyn. Earthq. Eng. 2017, 98, 1-11.4. [CrossRef]

56. De Bold, R.P. Non-Destructive Evaluation of Railway Track Bed Ballast. Ph.D. Thesis, School of Engineering, The University of Edinburgh, Edinburgh, UK, 2011.

57. Gavin, H.P. Vibrations of Single Degree of Freedom Systems; Class Note CEE201; Department of Civil and Environmental Engineering, Duke University: Dehan, NC, USA, 2014.

58. Chopra, A.K.; Chintanapakdee, C. Inelastic deformation ratios for design and evaluation of structures: Single-degree-of-freedom bilinear systems. J. Struct. Eng. 2004, 130, 1309-1319. [CrossRef]

59. Zola, M. Data Acquisition, Processing, Release to the Designers for Design Assessment; No. INIS-XA-584; Nuclear Power Institute of China: Chengdu, China, 2001.

60. Warburton, G.B. Optimum absorber parameters for various combinations of response and excitation parameters. Earthq. Eng. Struct. Dyn. 1982, 10, 381-401. [CrossRef]

61. Agilent Technologies. The Fundamentals of Modal Testing; Agilent Technologies: Santa Clara, CA, USA, 2000.

62. Molodova, M. Detection of Early Squats by Axle Box Acceleration. Ph.D. Thesis, Department of Road and Railway Engineering, Delft University of Technology, Delft, The Netherlands, 2013.

63. Ganesan, A.; Seshia, A.A. Tracking the Resonant Frequency of a Micromechanical Resonator Using Phononic Frequency Combs. arXiv 2017, arXiv:1710.07058.

64. BBC News. Kerala Floods: Monsoon Waters Kill Hundreds in Indian State. Available online: https://www.bbc.co.uk/news/world-asia-india-45216671 (accessed on 21 August 2018).

65. Kellermann, P.; Schönberger, C.; Thieken, A.H. Large-scale application of the flood damage model Railway Infrastructure Loss (RAIL). Nat. Hazards Earth Syst. Sci. 2016, 16, 2357-2371. [CrossRef]

66. Irazábal González, J. Numerical Analysis of Railway Ballast Behaviour Using the Discrete Element Method. Ph.D. Thesis, Department of Civil Engineering, Polytechnical University of Catalunya, Barcelona, Spain, 2017.

67. Freimanis, A.; Kaewunruen, S. Peridynamic Analysis of Rail Squats. Appl. Sci. 2018, 8, 2299. [CrossRef]

68. Network Rail. Flooding. Available online: https://www.networkrail.co.uk/running-the-railway/lookingafter-the-railway/delays-explained/flooding/ (accessed on 30 March 2017).

69. Wikipedia. Buoyancy. Available online: https://en.wikipedia.org/wiki/Buoyancy (accessed on 10 August 2018).

70. Liu, P.; Tang, B.-J.; Kaewunruen, S. Vibration-Induced Pressures on a Cylindrical Structure Surface in Compressible Fluid. Appl. Sci. 2019, 9, 1403. [CrossRef]

71. Liu, P.; Kaewunruen, S.; Tang, B.-J. Dynamic Pressure Analysis of Hemispherical Shell Vibrating in Unbounded Compressible Fluid. Appl. Sci. 2018, 8, 1938. [CrossRef]

72. Kaewunruen, S.; Sussman, J.M.; Matsumoto, A. Grand Challenges in Transportation and Transit Systems. Front. Built Environ. 2016, 2, 4. [CrossRef]

(C) 2019 by the authors. Licensee MDPI, Basel, Switzerland. This article is an open access article distributed under the terms and conditions of the Creative Commons Attribution (CC BY) license (http://creativecommons.org/licenses/by/4.0/). 